\title{
DISCOURSE AND DEINSTITUTIONALIZATION: THE DECLINE OF DDT ${ }^{1}$
}

\author{
STEVE MAGUIRE \\ Desautels Faculty of Management \\ McGill University \\ 1001 Sherbrooke Street West \\ Montreal, H3A $1 \mathrm{G} 5$ \\ Canada \\ Email: steve.maguire@mcgill.ca
}

Tel: 1-514-398-2115

Fax: 1-514-398-3876

and

\section{CYNTHIA HARDY}

Department of Management \& Marketing

University of Melbourne

Parkville

Victoria, 3010

Australia

Email: chardy@unimelb.edu.au

Tel: 61-3-8344-3719

Fax: 61-3-8344-3731

\footnotetext{
${ }^{1}$ The authors gratefully acknowledge the financial support of the Social Sciences and Humanities Research Council of Canada (SSHRC award number 410-2004-1665) and the Australian Research Council (Discovery funding scheme, project number DP 0771639).
} 


\title{
DISCOURSE AND DEINSTITUTIONALIZATION: THE DECLINE OF DDT
}

\begin{abstract}
Drawing on recent institutional theory emphasizing translation and discourse, this study explores outsider-driven deinstitutionalization through a case study of the abandonment of widespread and taken for granted practices of DDT use in the US between 1962 and 1972. Our findings illustrate how the abandonment of practices results from their problematization which, through a subsequent process of translation, changes discourse in ways that undermine the institutional pillars supporting practices through the emergence of new subject positions, from which actors speak and act in support of problematizations, and new bodies of knowledge, which normalize problematizations. We also introduce the concept of defensive institutional work purposive action aimed at countering disruptive institutional work - and illustrate how both disruptive and defensive work is carried out by authoring texts.
\end{abstract}


This study examines how the actions of individuals in producing, distributing and consuming texts can lead to radical change in an institutional field. Specifically, we examine the discursive dynamics associated with the deinstitutionalization of widespread, taken for granted practices of DDT use. Sales of DDT declined from over 67 million pounds in 1962, when it was the top selling insecticide in the US, to 22 million pounds in 1972, when a federal ban was announced. Our focus is on outsider-driven deinstitutionalization initiated in response to externalities linked to practices in a given field. The use of DDT was challenged, not by existing field members, but by actors who were not part of the field, such as Rachel Carson whose influential 1962 book - Silent Spring - was highly critical of DDT. Outsider-driven deinstitutionalization is especially relevant in today's world where calls are increasingly made for accepted - and profitable - business practices to be discontinued on the grounds of negative impacts on human health and the environment.

Despite its importance, outsider-driven deinstitutionalization has not been studied in detail. In fact, empirical studies of any form of deinstitutionalization are rare (Ahmadjian \& Robinson, 2001; Scott, 2001). When it is examined, it is often studied indirectly - as a byproduct of research on the adoption of new practices. As a result, we know little "about the work done by actors to disrupt institutions” (Lawrence \& Suddaby, 2006: 238). In addition, most studies of institutional change focus on projects initiated by actors inside the field; so we know little about the specific challenges faced by outsiders in bringing about field-wide change. Studies of insider-driven deinstitutionalization tend to provide evidence of changes that are "elaborative" rather than "reconstructive" (Colomy, 1998) in that they do not necessarily entail a significant redistribution of power, capital or membership in the field - dominant actors may do things differently but they often remain dominant (Hardy \& Maguire, 2008). However, some of the 
most pressing contemporary societal issues in which business is implicated - climate change, other environmental problems, corporate social responsibility, etc. - may require more radical change (Bartunek, Rynes \& Ireland, 2006). It is therefore important that we learn more about outsider-driven deinstitutionalization in a world where environmental and social values increasingly influence business practices.

To study outsider-driven deinstitutionalization, we draw on two emerging theoretical streams within institutional theory: work that uses the "translation" metaphor to understand institutional change (Zilber 2002); and organizational discourse theory (Phillips, Lawrence \& Hardy, 2004). The translation approach is premised on the idea that institutions are formed as meanings come to be shared and taken for granted. In contrast to the diffusion metaphor, which has dominated much of institutional theory and "connotes a transmission of a given entity", translation "connotes an interaction that involves negotiation between various parties, and the reshaping of what is finally being transmitted” (Zilber, 2006: 283). It focuses on the negotiation of shared meanings which make particular practices possible or, in the case of deinstitutionalization, make them illegitimate (Oliver, 1992). Organizational discourse theory tells us that texts are integral to the creation of meaning, but that they do not function individually or independently; instead meaning is created from collections of texts - or discourses - which evolve from the ongoing production, distribution and consumption of individual texts. Because "institutions are constituted through discourse” and discourse analysis has been used fruitfully to theorize institutionalization processes (Phillips et al., 2004: 635), our study explores the role of discourse in outsider-driven deinstitutionalization.

Our findings illustrate how individual acts of translation, cumulatively and over time, can change discourse at the macro-level and, in so doing, reconfigure power/knowledge relations in a 
field. In so doing, it makes a number of contributions. First, as an in-depth empirical study of deinstitutionalization, it adds to our understanding of a phenomenon on which there is a "paucity of literature” (Ahmadjian \& Robinson, 2001: 622). Second, we derive a series of propositions from our findings to provide a model of outsider-driven deinstitutionalization, which illustrates how translation and discourse are linked. Third, our study extends the work of institutional theorists who have examined how the use of language and rhetoric within a particular text helps to theorize institutional change (Suddaby \& Greenwood, 2005), by expanding the scope of study to include a focus on what happens to that text subsequently. Fourth, we introduce the concept of defensive institutional work, which is particularly relevant to outsider-driven deinstitutionalization - and institutional change more generally - as insiders attempt to defend existing practices. Finally, we identify some of the ways in which outsider-driven deinstitutionalization is likely to differ from deinstitutionalization driven by insiders.

The remainder of the paper is structured as follows. We first present the theoretical basis for this study by examining the relevant work in institutional theory and organizational discourse theory, and we develop two research questions. Second, we describe the case study - the deinstitutionalization of practices of DDT use - and the methods used to collect and analyze the data. Third, we present our findings. We conclude with a discussion of the study's implications.

\section{INSTITUTIONS AND DEINSTITUTIONALIZATION}

Consistent with other institutional theorists, we define institutions as "historical accretions of past practices and understandings that set conditions on action” through the way in which they acquire the "status of taken for granted facts which, in turn, shape future interactions and negotiations” (Barley \& Tolbert, 1997: 99). They are composed of cognitive, normative and regulative elements that "provide stability and meaning to social life” (Scott, 2001: 48). They 
govern behavior insofar as departures from institutionalized practices "are counteracted in a regulated fashion, by repetitively activated, socially constructed controls” that make deviations from institutionalized practices costly in one way or another (Jepperson, 1991: 145).

Institutionalized practices are held in place by three pillars - regulative, normative and cognitive - through which legitimacy is established and conformity secured (Scott, 2001). The regulative pillar refers to the authority of certain actors to formally constrain actors' behavior (Caronna, 2004). It involves the ability to establish rules, police conformity and, if necessary, coerce compliance (Scott, 2001). Conformity to legal rules, for example, occurs in response to these coercive pressures and is often the result of expedience (Hoffman et al, 2002) as actors seek to avoid the penalties associated with noncompliance (Hoffman, 1999). The normative pillar influences behavior by defining what is appropriate or expected in a given social situation (Wicks, 2001). It consists of values and norms that produce conformity (Caronna, 2004) as a result of social expectations and moral obligations (Hoffman et al., 2002; Scott, 2001). The cognitive pillar is based on "shared conceptions that constitute the nature of social reality" and define the prevailing orthodoxy (Scott, 2001: 57). Conformity in this case may be automatic and unconscious because of "a culturally supported and conceptually correct basis of legitimacy which becomes unquestioned” (Hoffman, 1999: 353). In these ways, institutional pillars help to reproduce behavior (Scott, 2001); institutionalized practices may be held in place at a particular point in time by one dominant pillar (Hoffman, 1999) or by an alignment of all three (Wicks, 2001). This tendency towards stability and reproduction does not, however, preclude change since it is possible for the pillars to become misaligned (Caronna, 2004) or for one or more to collapse (Ahmadjian \& Robbins, 2005), making deinstitutionalization more likely. 


\section{Outsider-driven Deinstitutionalization}

Most studies of institutional change focus on the adoption of new practices and insiderdriven change (Lawrence \& Suddaby, 2006). Our interest, however, is in situations where outsiders to the field initiate a "direct assault on the validity of a long-standing tradition or established activity” (Oliver, 1992: 567), which leads to the abandonment of existing practices.

Deinstitutionalization refers to the process whereby previously institutionalized practices are abandoned (Davis et al., 1994; Farjoun, 2002), not "merely because better options present themselves” (Ahmadjian \& Robinson, 2001: 627), but because practices have lost their original meaning. If an institution is a set of practices that has become legitimate and taken for granted (Douglas, 1986), then deinstitutionalization occurs when such legitimacy and taken-forgrantedness is called into question and the pillars that once held practices in place lose "their grip” (Ahmadjian \& Robinson, 2001: 621). The meanings of existing institutionalized practices are, however, not easy to change since they stem from belief systems that are well entrenched (Reay \& Hinings, 2005). Consequently some form of purposive “disruptive” institutional work (Lawrence \& Suddaby, 2006) is necessary to undermine these meanings.

Such institutional work is, however, likely to present outsiders with particular challenges in bringing about field-wide change. Outsiders are not located in dominant elite positions in the field and lack the centrality (Farjoun, 2002), communication networks (Lounsbury, 2001) and legitimacy (Phillips et al., 2004) of those actors whose practices they are seeking to discredit. In addition, outsiders’ efforts are also likely to encounter - so must overcome - “contrary organizational intentions to sustain the status quo” (Oliver, 1992: 578) i.e., opposition and resistance from insiders whose interests are threatened by the abandonment of existing practices (Hargadon \& Douglas, 2001; Anand \& Peterson, 2002; Hensman, 2003; Munir, 2005). It is 
therefore important to understand the mechanisms involved when outsiders try to bring about the abandonment of existing practices, and how they dislodge previously taken for granted meanings of these practices.

\section{Deinstitutionalization and Discourse}

One way to examine the meanings of institutionalized practices is to study the discourse about them (Phillips et al., 2004). Discourses are collections of interrelated texts (Parker, 1992), which "cohere in some way to produce both meanings and effects in the real world” (Carabine, 2001: 268). Texts are symbolic forms of representation (e.g., documents, books, media accounts, interviews and speeches, committee reports, etc.), which are inscribed by being spoken, written or depicted in some way, thereby "taking on material form and becoming accessible to others" (Taylor et al., 1996: 7). Discourses provide “a language for talking about a topic and ... a particular kind of knowledge about a topic” (du Gay 1996: 43). They define "who and what is 'normal', standard and acceptable” (Merilänn, Tienari, Thomas \& Davies, 2004: 544); as well as acceptable ways to think, talk and act (Hall, 2001). Discourses thus shape "the strategies and rules by which we can speak about and act on a domain ... in such a way that certain possibilities and outcomes are realized rather than others” (Reed 1998: 196). As a result, discourses produce “power/knowledge relations, linguistically communicated, historically located, and embedded in social practice” (Heracleous \& Barratt, 2001: 757). They are constitutive, rather than descriptive, of reality "through the way they make sense of the world for its inhabitants, giving it meanings that generate particular experiences and practices” (Phillips et al., 2004: 636).

“Discourses that are more coherent and structured present a more unified view of some aspect of social reality which becomes reified and taken for granted” (Phillips et al., 2004: 644). Accordingly, practices tend to be reproduced when the discourse about them is "structured" i.e., 
the texts that comprise the discourse draw on one another in well-established and understandable ways; and "coherent" i.e., these texts converge in their descriptions and explanations of social reality (Phillip et al., 2004). In this situation, institutionalized practices are reinforced and reproduced through two key mechanisms: subject positions (e.g., Oakes, Townley \& Cooper, 1998) and bodies of knowledge (e.g., Covaleski et al., 1998). First, subject positions include bureaucratic positions, as well as socially constructed and legitimated categories of identity (Bourdieu, 1990; Oakes et al., 1998), that "warrant voice” (Potter \& Wetherell, 1987). In any discourse, only "a limited number of subject positions are understood as meaningful, legitimate, and powerful” at a given point in time (Hardy, Lawrence \& Grant, 2005: 65). These subject positions provide the actors that occupy them with rights to speak and act (Maguire, Hardy \& Lawrence, 2004); and an increased likelihood that their text production will be consequential by influencing other texts and shaping the discourse (Phillips et al., 2004). Positions are not fixed but "negotiated and created by the maneuvering" of actors, as a result of which the ability to influence the field may change over time (Oakes et al., 1998: 260). Second, discourses are not simply a "way of seeing”: they reproduce a particular way of seeing as "truth” (Knights \& Morgan, 1991: 262); and they “'hook' into normative ideas and common-sense notions” to produce “ideas which convey messages, for example, 'good' and 'bad', morality and immorality, and acceptable and inappropriate behaviours” (Carabine, 2001: 269). Discourse thus creates bodies of knowledge which normalize certain ways of believing, speaking and behaving (Barge \& Oliver, 2003; Knights, 1992; Townley, 1993). In this way, both power and knowledge are implicated in discourse: "there is no power relation without the correlative constitution of a field of knowledge; nor any knowledge that does not presuppose and constitute at the same time power relations” (Foucault, 1979: 2; also see Covaleski et al., 1998). 
In sum, when practices are institutionalized (i.e. taken for granted and repetitively reproduced), subject positions tend to privilege dominant field incumbents who support the status quo; while bodies of knowledge tend to construct practices as effective, beneficial, appropriate, inevitable, etc., i.e. as unproblematic. If practices are to be abandoned, the discourse about them must change (Phillips et al., 2004; Munir, 2005; Maguire \& Hardy, 2006) but, so far, there is little research which explains how this occurs, especially in the case of outsider-driven deinstitutionalization. Accordingly our first research question is: What role does discourse play in outsider-driven deinstitutionalization?

Discourses are changed through the production, distribution and consumption of texts (Hardy \& Phillips, 2004; Parker, 1992). Accordingly, our starting point for deinstitutionalization is the production of texts which include claims, arguments, stories, examples, statistics, anecdotes, etc. that "substantiate and dramatize the ineffectiveness and injustice of existing practices” (Colomy, 1998: 289). We refer to such claims as "problematizations.” In the case of outsider-driven deinstitutionalization, outsiders can produce and distribute texts to promote particular meanings of practices i.e. as problematic; and to build a case for their abandonment. Problematizations of institutionalized practices are inscribed in texts in order to allow these ideas to travel in space and time (Callon, 1991; Czarniawska \& Joerges, 1996), i.e. across "separate and diverse local settings” (Smith, 1990: 168).

Actors can try to make problematizations more persuasive to their audiences through the use of, for example, various rhetorical strategies (e.g., Suddaby \& Greenwood, 2005) or particular collective action frames (Benford \& Snow, 2000) to "provide an interpretation of the situation and frame courses of action that appeal to existing interests” (Fligstein, 2001: 112). In these ways, individuals try to "manage meaning” and "de-legitimize" the status quo (Pettigrew, 
1979). Meaning is, however, neither unequivocal nor inherent to a text; nor is it simply passed intact from one text to another; instead, it is negotiated between the text's author and its readers (Czarniawska, 1997) as the text is consumed i.e., read and interpreted. This has been referred to as translation, a concept derived from the French philosopher Michel Serres (Brown, 2002; Czarniawska \& Sevón, 1996) that has been widely used in actor-network theory (Callon, 1986; Latour, 1986) and adopted in organization studies by Czarniawska and Sevón (1996) and Zilber (2006) to explore institutionalization. The notion of translation is used to break away from the diffusion model and to draw attention to the way that meanings, rather than being passed on intact, inevitably change as they travel in space and time (Zilber, 2006). "To translate is to transform, and in the act of transforming a breaking of fidelity towards the original source is necessarily involved” (Brown, 2002: 7).

In the context of our study, the concept of translation refers to how problematizations like claims (Latour, 1986), generic rational myths (Zilber, 2006) or other forms of ideas (Czarniawska \& Joerges, 1996) - do not diffuse intact and unchanged through a field but are transformed as actors read a text and interpret the problematizations that it contains. If the reader then goes on to author and distribute his or her own texts, they will re-state the problematizations in different ways and with varying degrees of fidelity to the original (Brown, 2002). For example, opponents may try to deny problematizations by articulating "counter-narratives to discredit the project and its advocates” (Colomy, 1998: 290). Supporters, by interpreting problematizations in different ways - agreeing with some aspects and disagreeing with others or by presenting them for different audiences - are likely to change them in the texts they produce and distribute. Each individual translation may then itself be translated as it, too, is subsequently consumed; and so on. Cumulatively, these individual acts of translation add up to an ongoing process of translation. 
The question that remains is: if outsiders are to bring about the abandonment of practices, what happens to their problematizations during this process of translation? While there is a considerable amount of work that examines how framing and rhetoric can be incorporated into individual texts to maximize the appeal of particular problematizations (e.g., Benford \& Snow, 2000; Suddaby \& Greenwood, 2005), little research has been conducted on what happens to problematizations after the text is produced i.e., whether and how problematizations are translated in ways that lead to deinstitutionalization at the level of the field. Thus our second research question is: what role does the process of translation play in outsider-driven deinstitutionalization?

\section{CASE STUDY AND METHODS}

DDT, or dichlorodiphenyltrichlorethane, originally synthesized in 1874, became the top selling insecticide in the US. Large scale manufacture began during the Second World War to protect troops from typhus, malaria and other insect-borne diseases. After the war, it was released into the civilian economy and, on the recommendation of the Department of Agriculture, widely used on crops, including cotton, tobacco and many foodstuffs. DDT was also used on the farm to protect livestock against insects; in the home against flies, roaches, and bedbugs; in forestry against insects that defoliated trees; and in suburban neighborhoods against mosquitoes and bark beetles which spread Dutch elm disease. In accordance with the 1947 Federal Insecticide, Fungicide and Rodenticide Act, manufacturers were required to register the labels of their products with the Department of Agriculture before commercializing them, and to provide evidence of product safety and efficacy when used according to the label. Tolerances for acceptable levels of DDT residues on foodstuffs were established by the Food and Drug Administration, part of the Federal Security Agency (which in 1953 became the Department of 
Health, Education \& Welfare). Sales grew quickly as more DDT was applied than any other insecticide - US usage peaked in 1959 at 79,000,000 lbs (EPA, 1975: 149) - and it remained the top-selling insecticide into the early 1960s (see Figure 1).

\section{—Figure 1 about here-}

DDT was credited with saving millions of lives during the war and Paul Muller, the researcher who had discovered its insect-killing properties in 1939, was awarded the 1948 Nobel Prize in medicine. From the 1950s, however, evidence concerning problems with DDT started to accumulate: its efficacy against certain pests was called into question due to resistance, resurgence and secondary pests; and some toxicologists were questioning DDT's safety for humans, especially after it was established that DDT residues were accumulating in the fat of US citizens. In addition, because measurable quantities were being detected in birds, fish and wildlife as well as soil and water, government reports (especially by the Fish and Wildlife Service, part of the Department of the Interior) and articles in specialized scientific journals were beginning to catalogue the ubiquity of exposure to, and possible risks posed by, DDT.

Despite these studies, widespread practices of DDT use changed little until the appearance in 1962 of Rachel Carson’s book Silent Spring, serialized in the New Yorker in June and July, and published in September. It describes in detail the problems that pesticides, including DDT, posed for human health and the environment, directly challenging taken for granted practices of pesticide use. It opens with an apocalyptic tale, describing a fictional town marked by "a shadow of death" as a result of problems caused by pesticides, including "new kinds of sickness" and the deaths of children. Instead of a spring marked by birdsong, "only silence lay over the fields and woods and marsh" (p. 2). The chapter closes by noting that this “town does not actually exist” but could "easily become a stark reality" if practices of pesticide use were not changed (p. 3). 
Subsequent chapters describe a range of problems associated with pesticides, with some affecting farmers but most affecting the public and the environment - birds, fish and wildlife, as well as the ecosystems in which they lived. The concluding chapter made a case for substituting DDT and other chemicals with biological control of insects, although Carson (1962: 12) did clarify that it "is not my contention that chemical insecticides must never be used".

The book was widely reviewed and sales surpassed 500,000 copies by April 1963. It caught the attention of the scientific community and was reviewed in scientific journals such as Ecology and Science. It provoked strong reactions from agribusiness and the chemical industry, which countered with their own texts that challenged its claims, and triggered a flurry of activity in the political arena. Portions of the New Yorker serialization were read directly into the Congressional Record; politicians wrote to Carson for advice; while President Kennedy answered a reporter's question on pesticides by referring to Carson by name, and instructed his President's Science Advisory Committee (PSAC) to investigate. PSAC's 1963 report called for the elimination of DDT and other pesticides, and other government reports followed (e.g. Mrak, 1969; Ribicoff, 1966). Non-government organizations (NGOs), such as the Environmental Defense Fund, pressured governments to take action against DDT. In 1968, Wisconsin held hearings which concluded that DDT was a water pollutant under state law and, by 1969, several states had enacted local bans affecting various uses. In response to a 1971 court order issued as a result of a petition by the Environmental Defense Fund, the Environmental Protection Agency (EPA), which had been created in 1970, initiated hearings on DDT’s status. In 1972, the EPA banned DDT nation-wide, effective from 1973. By this time, however, practices of DDT use had already been largely abandoned voluntarily, with usage down by more than 67\% from 1962 levels. 


\section{Research Design, Site Selection and Data Collection}

We use a single, exploratory case study to build theory. Single cases are a common research method for building theory (Dyer \& Wilkins, 1991; Yin, 2003) and have been used to study institutional change, including research using the translation metaphor in which a deep, interpretive and holistic understanding is required (e.g., Suddaby \& Greenwood, 2005; Zilber, 2002). We selected this particular case because it is a clear, well-documented example of outsider-driven deinstitutionalization for which data collection and analysis were feasible - many primary texts are in the public domain and detailed historical accounts exist. In addition, because of the acknowledged role of Silent Spring in the abandonment of practices of DDT use, as well as the fact that subsequent struggles around its problematizations are well-documented, discursive changes and the process of translation were "transparently observable” (Eisenhardt, 1989: 537).

We began by collecting data in the form of secondary accounts (Blodgett, 1974; Bosso, 1987; Dunlap, 1981; Lear, 1997) to ensure convergence and triangulation on events. From these, key primary sources were identified and a series of texts was assembled for analysis (e.g., Silent Spring; a CBS television documentary entitled The Silent Spring of Rachel Carson broadcast in April, 1963; book reviews; government reports; transcripts; and scientific articles). In 1998-9, we interviewed several individuals, including: Shirley Briggs (a longtime friend of Carson and retired head of the Rachel Carson Council); two EPA employees from the time of the ban (an insecticide expert and an economist); and an eminent entomologist who had served on government committees addressing DDT. We also accessed, from the State Historical Society, tape recordings of seven interviews conducted in 1971-2 by historian Thomas Dunlap with participants in hearings held on DDT in Wisconsin in 1968, including members of the Environmental Defense Fund who opposed DDT, supporters of DDT, and the hearing examiner. 


\section{Data Analysis}

We first developed a narrative account (Eisenhardt \& Bourgeois, 1988) that chronicled the abandonment of institutionalized practices of DDT use. We constructed an "event history database” (Van de Ven \& Poole, 1990) using the interviews and secondary sources, chronologically ordering descriptions of the process leading to the abandonment of DDT and juxtaposing accounts from different sources to ascertain convergence. This analysis captured "who did what; and when”. For each event, relevant primary sources - government reports, scientific publications, hearing transcripts, etc. - were identified and chronologically ordered to comprise a "discursive event history database” (Maguire, 2004) i.e., "who said what, and when”. From these, we prepared a narrative account of the process through which practices of DDT use were deinstitutionalized which formed the basis of our case study description, presented above.

In the second stage of analysis, we analyzed the structure of Carson’s book; summarized the content of each chapter; and, by coding these summaries, identified whether and how they problematized existing institutionalized practices. We identified three meanings of DDT use taken for granted at the time - that were problematized in the book: DDT was (1) safe; (2) effective; and (3) necessary (see Figure 2). These problematizations led Carson to call for legislative change on the basis of scientific evidence (Figure 2 shows the number of references for each chapter), as well as her critique of the morality of practices of DDT use in relation to environmental values and individual rights: “enormous numbers of people” were subjected to "contact with these poisons, without their consent and often without their knowledge” (Carson, 1962: 12). In combining factual arguments, ethical reasoning, and critiques of the legislative status quo, Silent Spring represented an attempt to undermine each of the cognitive, normative and regulative pillars supporting practices of DDT use. 
—Figure 2 about here-

Our next stages of analysis addressed whether and how changes in the discourse of practices of DDT use occurred. The third stage of analysis was cross-sectional. We identified texts we could compare at two points in time: in 1962, when Silent Spring appeared and DDT was the top-selling insecticide, with practices taken for granted; and in 1972, when DDT was banned. For the regulative pillar, we compared the contents of federal legislation in effect in 1962 and 1972. For the cognitive pillar, we compared the content of textbooks from two scientific disciplines: applied entomology, which might be expected to be biased in favor of DDT; and ecology, which might be expected to be biased against it. We sought textbooks for which different editions had been published before and after Silent Spring and made our final selection based on advice from colleagues in entomology and ecology. It was more difficult to identify relevant texts that could be compared at the two points in time in relation to the normative pillar. In the end, we opted to compare the 1962 New York Times editorial following publication of Silent Spring with its 1972 editorial following the ban, as an indicator of opinion concerning the “rightness” or "wrongness” of practices of DDT use. In our analysis of each pillar, we coded for whether and how these texts constructed DDT as safe, effective and necessary at the two points in time. In this way, we were able to identify new bodies of knowledge.

Our fourth stage involved a longitudinal investigation where we identified a selection of texts addressing DDT between 1939 (when DDT's insect-killing properties were first discovered) and 1972 (when DDT was banned), and associated with each of the three pillars. For the regulative pillar, we examined the texts of all federal regulations and administrative rulings affecting practices of DDT use between 1939 and 1972. For the cognitive pillar, because the scientific literature on DDT consisted of a massive volume of texts, we analyzed $\mathrm{PhD}$ 
dissertations to capture the frontiers of scientific knowledge, and articles in Science to capture additions to scientific knowledge considered important by the scientific community. Using the Proquest Dissertations and Theses and Reader's Guide to Periodical Literature databases, we retrieved dissertations and Science articles from 1939 to 1972 with DDT in their title or as a keyword. For the normative pillar, we examined a range of texts, including all New York Times editorials from 1939 to 1972 mentioning DDT; texts produced NGOs, which made ethical arguments against DDT; and reports produced by ad-hoc government advisory committees whose recommendations, while they had no legal weight or direct legislative impact, drew conclusions about the appropriateness of practices of DDT use (Mrak, 1969; PSAC, 1963; Ribicoff, 1966). ${ }^{2}$ We complemented our analyses of these texts with secondary data on letters written to editors and publishers in response to Silent Spring. We coded these text for whether and how they constructed DDT as safe, effective and necessary over time to identify the specific ways in which the problematizations were translated. We also examined changes in the pattern of text authorship to establish whether new actors began to produce texts. By further examining whether the texts of new actors were consequential - whether their texts influenced and were referenced in other texts; whether the groups were viewed as legitimate; and whether power/knowledge relations were changed, we were able to identify new subject positions.

Our final stage involved an analysis of counter-texts. Because of the large volume of counter-texts that existed, we focused on key texts identified from our discursive event history database, including scientific texts submitted in evidence to formal hearings on behalf of industry and government; articles in trade journals; and scientific journal articles. We then coded these

\footnotetext{
${ }^{2}$ We categorized government reports as normative rather than regulative because they were merely advisory: the government was neither bound by their conclusions nor obliged to implement their recommendations. Any impact is thus normative rather than coercive. Texts that were backed by the coercive power of government, such as administrative rulings, court orders and acts of legislation, were considered in connection with the regulative pillar.
} 
texts for whether and how they countered the problematizations promoted in Silent Spring.

\section{FINDINGS}

Silent Spring problematized practices of DDT use - as not safe, effective or necessary and, in so doing, made a case for institutional change. Our findings illustrate that the pillars supporting taken for granted practices were not dismantled single handedly by Silent Spring, but as a result of the process of translating its problematizations. Over time, the discourse that gave practices of DDT use their meaning changed, leading to the abandonment of DDT: new subject positions emerged from which actors spoke and took action in support of problematizations, which became normalized in new bodies of knowledge. Our findings are organized around the pillars to illustrate how each was undermined despite efforts to defend them.

\section{The Cognitive Pillar}

Texts associated with the cognitive pillar can be particularly consequential in a case such as this because their authors - as scientific “experts” - are typically considered authoritative. As a result, they play an important role in constructing scientific orthodoxy through so-called “factmaking” (Maguire, 2004). Our analysis indicates that Silent Spring provoked a flurry of scientific texts that, collectively and over time, weakened the cognitive pillar as existing "facts" about DDT were increasingly contested by scientists outside the discipline of economic entomology, where DDT had traditionally been researched. In this way, new subject positions emerged in the discourse of DDT, and the problematization of DDT's safety for the environment survived the process of translation as assertions of DDT's environmental impacts became normalized as new scientific "facts".

\section{Normalization of problematizations}

Silent Spring and the controversy it generated prompted new patterns in the production, 
distribution and consumption of scientific texts; the book was reviewed in scientific journals; and its claims were studied and evaluated in countless other research reports. This is evidenced by the increased number and proportion of PhD dissertations and Science articles addressing DDT's safety (i.e. its impacts on non-insect life such as birds, fish and mammals, including humans), as opposed to its efficacy (i.e. its impacts on insects). Figures 3a and 3b divide research into the following categories based on the topic addressed - insects, birds, fish, mammals (including humans), environmental persistence, regulation, and chemistry. These categories broadly correspond to safety, efficacy and necessity: texts on insects address efficacy; those on birds, fish, mammals and environmental persistence address safety; those on regulation address safety and necessity. ${ }^{3}$ Prior to 1962, the dominant category was insects (research on DDT's efficacy) with 84\% of dissertations and 57\% of Science articles. There was relatively little research on DDT's safety - only 3\% of dissertations and 18\% of articles addressed DDT's impacts on birds, fish and mammals or its persistence. Publications addressing these latter topics increased significantly during 1962-1972 to comprise $67 \%$ of dissertations and 70\% of articles, while those addressing DDT's efficacy against insects declined to only $27 \%$ of dissertations and $4 \%$ of articles. This analysis suggests that scientific texts addressing DDT's safety made up an increasingly larger proportion of DDT discourse subsequent to Silent Spring. Science articles on regulation also increase after 1962, indicating that DDT's necessity became part of the research agenda.

—Figures 3a and 3b about here-

This is not to say that the problematizations in Silent Spring were immediately or completely accepted by the scientific community. The 1962 review in Science was negative, labeling Carson's treatment of the issue as unbalanced in that it ignored the benefits of pesticides,

\footnotetext{
${ }^{3}$ Research addressing chemistry is not directly related to safety, efficacy or necessity - it is concerned with how to synthesize DDT and how to identify it in samples of biological materials.
} 
and claiming that "most scientists who are familiar with the field ...feel that the danger of damage [on humans and wildlife] is slight” (Baldwin, 1962: 1042). Other scientific texts also countered the problematizations in Silent Spring. Over time, however, as more scientific texts were produced, distributed and consumed, counter-texts became more selective about which problematizations they criticized and how they criticized them. As a result, the problematization of DDT's presumed safety for the environment survived the process of translation to become normalized - assertions of DDT's environmental impacts were transformed into facts that appeared in textbooks, to be taught by academics and read by students as part of the new scientific orthodoxy on DDT. Table 1a presents evidence of this by comparing the 1962 and 1971 editions of a textbook on applied entomology. Whereas the earlier edition notes only a few "disadvantages" affecting farmers and none affecting the environment, the later edition acknowledges environmental problems with DDT: persistence in soil, accumulation in organisms, and biological magnification via food chains are all asserted. Table $1 \mathrm{~b}$ provides similar evidence from a comparison of two editions of an ecology textbook: the later edition asserts “the poisoning of entire food chains” as well as DDT’s negative impacts on bird populations without qualification and with explicit reference to Silent Spring, and links DDT to "one of the world's most serious pollution problems" due to its negative impacts. The problematization of human safety also survives the translation process but in qualified form: the entomology textbook qualifies it by expressing "concern" only in relation to "possible" chronic impacts; while the ecology text book qualifies it by saying the threat is "not yet demonstrated" but "could" occur. With respect to efficacy, both the entomology and ecology textbooks had already acknowledged problems of resistance prior to Silent Spring and they continued to do so in the later editions, however there is little evidence that concern over this problem was 
significant or changed much: the ecology text makes only passing reference to resistance; while the entomology textbook minimizes the problematization of efficacy by stating that resistance is "limited to relatively small areas". This analysis yielded no evidence that the problematization of DDT's necessity promoted in Silent Spring survived the translation process: coverage of biological controls was similar - and quite limited - in both editions of each text book. — Tables $1 \mathrm{a}$ and $1 \mathrm{~b}$ about here-

\section{New subject positions}

Changes in the pattern of authorship of scientific texts also occurred: prior to 1962, the majority of sampled texts were produced by economic entomologists; after 1962 scientists from other disciplines were producing texts. We found that of the 69 dissertations prior to 1962, 61\% were from entomologists or agricultural scientists; while only $17 \%$ were from biologists or zoologists. In contrast, of the 102 dissertations from 1962-1972, only 22\% came from entomology or agricultural science; while $54 \%$ came from a wide range of disciplines concerned with the impact of DDT on human health and the environment, including biology, ecology, ecotoxicology, nutrition, soil science, and zoology. Similarly, of the 67 articles in Science prior to 1962, 43\% were from entomologists or agricultural scientists; while $18 \%$ were from biologists or zoologists. Of the 71 articles after 1962, only 10\% came from entomology or agricultural science; while 65\% came from disciplines concerned with DDT's safety for humans and the environment.

The changes in patterns of authorship indicate that scientists working in disciplines other than economic entomology had begun to participate much more actively in scientific discussions of DDT, challenging the previously dominant economic entomologists. As more $\mathrm{PhD}$ dissertations and articles were published by these researchers, their research and expertise became more valuable to others involved in decision making; and their texts were widely 
consumed. For example, Dr. Charles F. Wurster Jr., a biology professor who studied the impact of pesticides on birds, addressed DDT in Science eight times between 1965 and 1972, worked closely with the Environmental Defense Fund, and testified against DDT at formal hearings; while Dr. Joseph J. Hickey, a wildlife ecologist whose work linked DDT to the thinning of eggshells, also published in Science and testified at formal hearings.

The problematization of DDT's safety for the environment in Silent Spring thus played an important role in the emergence of new subject positions in the discourse of DDT; Carson's book was an important catalyst in the development of ecotoxicology (Wright \& Welbourne, 2002) and ecology (Kudlinski, 1988), from which flowed a growing stream of increasingly consequential scientific texts describing DDT's negative impacts. As legitimate, authoritative voices, these disciplines challenged the previously dominant position of economic entomology by speaking and acting in support of problematizations and, in so doing, creating a new body of scientific knowledge about DDT.

To conclude, the cognitive pillar that supported existing DDT practices was undermined as previously taken for granted facts underpinning DDT's presumed safety for the environment were initially contested and, over time, replaced by new ones. Subsequent to Silent Spring, more individual scientists from outside economic entomology started to participate in scientific discussions of DDT by conducting research and publishing articles. Over time, new subject positions emerged in the discourse of DDT as disciplines such as ecology and ecotoxicology became established as ongoing contributors to knowledge about DDT. This led to even more research on the negative impacts of DDT which, in turn, generated more texts that increasingly converged in their descriptions of reality: that DDT was not safe for the environment became normalized in a new body of scientific knowledge. 


\section{The Normative Pillar}

Our analysis illustrates how Silent Spring sparked a public debate generating a large volume of texts that, collectively and over time, weakened the normative pillar as individual actors increasingly contested the appropriateness and desirability of DDT use. Over time, new subject positions - the public as well as environmentalist NGOs and politicians speaking on its behalf - emerged in the discourse of DDT; and the problematization challenging DDT's presumed safety for the environment survived the process of translation to become normalized in a new body of knowledge making a moral case for abandoning DDT.

\section{Normalization of problematizations}

Silent Spring was widely consumed in the public arena - sales exceeded half a million copies in the first year and CBS's documentary reached over 10 million people. As a result, members of the public increasingly saw themselves as having an interest in curtailing practices of DDT use, and they responded by speaking out against DDT. According to secondary sources, many thousands of citizens wrote letters to Carson, her publisher, The New Yorker, CBS television, newspapers and government agencies, with the vast majority voicing support for Silent Spring’s problematizations and normative conclusions (Coit Murphy, 2005; Lear, 1997). For example, 98\% of the published and unpublished letters to the New Yorker praised the book or its serialization (Coit Murphy, 2005). By producing and distributing their own texts - writing letters to editors and politicians, participating in call-in radio debates, and signing petitions to halt spraying campaigns - the public began to question the appropriateness and desirability of DDT.

Editorials from the New York Times also indicated growing support for abandoning DDT. Prior to 1962, there had been no call for a ban and most editorials had praised DDT's insectkilling properties, with only two (in 1959 and 1961) mentioning possible negative impacts. In 
July 1962, the editorial reported on Silent Spring, praising it for initiating a public debate about DDT. Table 2 presents evidence that, in the editorials between 1962 and 1972, the problematization of environmental safety was taken up during the process of translation (i.e. negative impacts on the environment are asserted); the problematization of human safety was qualified (i.e. negative impacts on human health are "possible"); the problematization of DDT's efficacy was of little concern in the public debate; and the problematization of necessity was subverted insomuch as other chemicals, criticized in Silent Spring, were viewed as acceptable substitutes for DDT, whereas biological controls required more research and development.

—Table 2 about here-

NGOs also produced texts questioning the appropriateness of using DDT on moral grounds. The Environmental Defense Fund existed, in the words of one member, to "define human rights through research, education and litigation” (Woodwell quoted in Dunlap, 1981: 147). It maintained that practices of DDT use were inappropriate because everyone had the right "to full benefit, use and enjoyment of the national natural resource treasure ... without degradation or diminution in value resulting from the use of the broad spectrum, persistent, chemical biocide DDT"; and invoked intergenerational equity to extend this right to "generations yet unborn” (Henkin, Mertle \& Staples, 1971: 16). Similarly, members of the Audubon Society were exhorted to "stop this gambling with the balance of nature and the lives of people ... Why must innocent creatures and valuable plant life suffer? Just so a small minority can make money? Thank God for crusaders such as Rachel Carson!”(Long, 1962: 299).

Political opinion also began to change: no government text had recommended the elimination of DDT prior to 1962 and, in fact, the Department of Agriculture recommended it to farmers for use on a wide variety of crops. But three important government advisory reports 
subsequently recommended abandonment, supporting the conclusions in Silent Spring that practices were inappropriate and undesirable. Table 3 indicates that the problematization of DDT's safety for the environment is taken up during the process of translation and appears in all three reports (i.e. DDT's negative impacts on the environment are asserted); the problematization of DDT's safety for humans is qualified (i.e., DDT's negative impacts on humans are regarded as not proven, but neither is its safety); the problematization of DDT's efficacy was of little concern in the advisory reports; and the problematization of necessity was subverted (i.e., all reports are skeptical of the viability of biological controls and advocate other chemicals criticized in Silent Spring but which are more targeted and less persistent than DDT).

—Table 3 about here-

\section{New subject positions}

Over time a number of new subject positions emerged. One important new subject position was the public, which came to be accepted as legitimate contributors to the debate over DDT. Following the publication of Silent Spring, the public wrote letters to newspapers, government agencies and politicians in support of its problematizations (Coit Murphy, 2005;

Lear, 1997). NGOs and politicians also then began authoring texts in support of problematizations, speaking on behalf of the public. They too became accepted, ongoing contributors to the debate over practices of DDT use, resulting in other new subject positions. One prominent environmental NGO, for example, was the Environmental Defense Fund, mentioned above, which was formed in 1967 to address DDT specifically. In addition, existing conservation organizations, such as the Audubon Society, grew in membership and joined the fight against DDT, largely as a result of Silent Spring (Bosso, 1987). These NGOs produced more texts that challenged the continued use of DDT on moral grounds, asserting its negative impacts 
on the environment and humans and calling for a ban. NGOs' texts were increasingly consequential, informing the public, the media and formal hearings as NGOs launched campaigns and found arenas in which the restriction or abandonment of DDT could be formally debated. For example, the Brookhaven Town National Resources Committee made an unsuccessful attempt to halt the spraying of DDT by the Suffolk County Mosquito Control Commission in New York in 1966; while the Citizens' Natural Resources Association of Wisconsin and the Environmental Defense Fund were successful in having DDT declared as a water pollutant in Wisconsin in 1970.

The other new subject position was that of environmental politicians: as they began to acknowledge that the public "warranted voice" on the matter of pesticides, and that DDT was a legitimate issue for the political agenda, politicians also started to author texts problematizing DDT and which were consequential. Immediately following its publication, portions of Silent Spring were read into the Congressional Record; state legislatures across the US were presented with some 40 bills addressing pesticides; and, in 1965, Senator Gaylord Nelson of Wisconsin tried to introduce (ultimately unsuccessful) legislation seeking to ban DDT. He also testified against DDT at the Wisconsin hearings in 1968. In addition, there were the PSAC, Ribicoff and Mrak reports discussed above and summarized in Table 3.

To conclude, the normative pillar that supported existing DDT practices was undermined as previously taken for granted conclusions regarding the appropriateness and desirability of DDT were challenged and a moral case for abandonment was made by members of the public, as well as individual NGOs and politicians. The public as well as environmental NGOs and politicians speaking on its behalf became accepted as ongoing contributors to discussions of DDT and their texts were consequential: together, these three new subject positions represented an environmental lobby that acted as a counterweight to the powerful agricultural lobby that 
defended practices of DDT use. As texts converged in their descriptions of DDT as inappropriate due to negative impacts on the environment, and in their recommendations that DDT be substituted by other chemicals, the opinion that DDT was not safe for the environment or necessary became normalized in a new body of lay and political knowledge.

\section{The Regulative Pillar}

In 1962 the federal legislation governing pesticides was the 1947 Federal Insecticide, Fungicide and Rodenticide Act, which did not single out DDT for special attention. Our analysis suggests that Silent Spring provoked a series of texts backed by the coercive power of government which, collectively and over time, undermined the regulative pillar. Some of these texts were authored by new government actors, most notably the EPA, an important new subject position, which issued the $1972 \mathrm{ban}$. The text of the ban indicates that the problematization of DDT's presumed safety for the environment survived the process of translation to become normalized in a new body of law restricting the use of DDT.

\section{Normalization of problematizations}

Silent Spring is credited by actors at the time with giving rise to a range of legislative texts: "Rachel Carson used her superb writing skill and the inspired allegory of a bird's song to tap a full reservoir of public anxiety over chemical pesticides in our environment. The reaction to the raising of this issue extended throughout Government ... New legislation was passed and the executive agencies realined (sic) their policies to deal with the problem” (Ribicoff, 1966: 1-2). These texts included a 1964 amendment of the 1947 Act to close a loophole and prevent manufacturers from registering pesticides under protest, making it easier for the Department of Agriculture to cancel pesticide registrations, which it did: from 1967 to 1970, citing concerns over DDT's negative impacts on the environment, the Department of Agriculture issued 
cancellation notices affecting DDT use in a series of minor markets.

In 1972, the Administrator of the EPA announced a ban on the use of DDT. The text of his Opinion and Order refers directly to some of Silent Spring’s problematizations. Table 4 suggests that the problematization of DDT's safety for the environment survived the process of translation - DDT's negative impacts on the environment, such as its thinning of bird eggshells, are asserted. The problematization of DDT's safety for humans also survived the process of translation, although in qualified form - DDT was a "potential” carcinogen. DDT’s efficacy was not a consideration. DDT's necessity, on the other hand, was - the issue of substitutes figures prominently in the Opinion and Order. The problematization of DDT's necessity survived the process of translation but in subverted form: although the EPA Administrator found that DDT was not necessary, it was not because DDT could be economically substituted with biological controls as advocated in Silent Spring, but because it could be substituted by other chemicals that had been criticized in Carson’s book.

— Table 4 about here-

\section{New subject positions}

One new subject position was created as a result of a 1964 Interdepartmental Agreement on Coordination of Activities Relating to Pesticides between the Departments of Agriculture, Interior, and Health, Education \& Welfare, and attributed to Silent Spring (Ribicoff, 1966) - the Federal Committee on Pest Control. It replaced the Federal Pest Control Review Board and was given greater authority to address regulation, research, and information programs, in addition to pest control programs. By far the most significant new subject position, however, was the EPA, whose creation in 1970 has also been directly attributed to Silent Spring (Lewis, 1985; Wilson, 2002). As compared to the Federal Committee on Pest Control, the EPA was far larger - between 
1970 and 1972, the EPA’s budget and workforce more than doubled to almost $\$ 2.5$ billion and 8,358 employees - and more powerful. Pesticides were a key priority for the EPA - the Pesticides Office was the only one of five programmatic offices to focus on a particular industry and its products. ${ }^{4}$ Moreover, DDT was a particular concern because of the intense public and political interest. It also represented an opportunity for the new agency to send an early message about how staunchly it would protect the environment.

The EPA took over responsibility for: pesticide registrations from Agriculture; research on the safety of pesticides for humans and the setting of pesticide residue tolerances from Health, Education \& Welfare; and research on the safety of pesticides for the environment from the Interior. For the first time, a single agency was responsible for considering the interests of the public and the environment, in addition to those of farmers, in regulating pesticides. It thus represented a major realignment of both interests and authority in the field. As its first Administrator said, "EPA is an independent agency. It has no obligation to promote agriculture or commerce; only the critical obligation to protect and enhance the environment” (Ruckelshaus, 1970). Accordingly, the EPA represented a powerful new subject position in the discourse of DDT: a legitimate government unit mandated to exercise voice and to act to protect the environment; and whose texts were extremely consequential, particularly in the case of the ban.

To conclude, the regulative pillar that had previously sanctioned practices of DDT use was undermined as legal texts increasingly restricted its use based on problematizations from Silent Spring. Over time, new subject positions emerged, the most important of which was the EPA. As legal texts converged in their descriptions of DDT as inappropriate due to negative impacts on the environment and as substitutable by other chemicals, $t$

\footnotetext{
${ }^{4}$ Other Offices were concerned with pollution as an unintended by-product of industrial processes, as with the Water Quality and Air Pollution Control Offices.
} 


\section{Defending the Institutional Pillars}

To counter the growing number of texts asserting DDT’s negative impacts, characterizing practices of DDT use as inappropriate and calling for restrictions, a number of actors produced “counter-texts” and, in so doing, mounted a defense of the institutional pillars supporting practices of DDT use. For example, the National Agricultural Chemicals Association produced a pamphlet called “Fact and Fancy” which directly countered Carson’s “allegations” with the industry’s “facts” (NACA, 1962). The National Pest Control Association sent a collection of negative reviews of Silent Spring to its members and included a song parody, which included the lines: “Hunger, hunger, are you listening / To the words from Rachel’s pen? / Words which taken at face value / Place lives of birds above those of men” (reprinted in Lear, 1997: 435). Monsanto parodied the opening chapter of Silent Spring with a publication that described a "desolate” world of plagues and starvation without pesticides (Monsanto, 1962: 9). Dr. Robert White-Stevens of American Cyanamid warned during the CBS documentary: "If man were to faithfully follow the teachings of Miss Carson, we would return to the Dark Ages, and the insects and diseases would once again inherit the earth” (CBS, 1963). The Time review of Silent Spring called it Carson’s “emotional and inaccurate outburst (September 28, 1962: 48); while William Bean MD (1963: 65) concluded that Silent Spring, which he read "with some trauma”, reminded him of "trying to win an argument with a woman. It cannot be done.”

In defending the cognitive pillar, counter-texts used science to challenge the factual basis of the problematizations. For example, in countering the problematization of DDT's safety for the environment, Time (September 28, 1962) invoked the National Academy of Science, which had sponsored a "careful" study that concluded that its negative impact on the environment "though always regrettable, is not disastrous” (p. 48). In relation to the problematization of DDT's safety 
for humans, Jamie L. Whitten, chair of the House Appropriations Sub-Committee on Agriculture, reported on interviews of 185 “outstanding” scientists and 23 physicians in his book That We May Live. It stated that "The American Medical Association and other authorities advised ... that there is no proof that traces of chemical pesticides cause either cancer or sterility in humans” (Whitten, 1966: 127). Max Sobelman of the Montrose Chemical Corporation argued that the attacks against DDT were "emotional in nature" and "the arguments used are based on halftruths, exaggeration and innuendo"; while those who defended DDT were "qualified scientists and responsible industry spokesmen” (Sobelman, 1970: ii). The problematization of necessity i.e., the availability of acceptable alternatives was also challenged using science: Agricultural Chemicals (June 1967) argued that DDT was needed because research on biological controls hadn’t "shown much” and would "probably only come very slowly” (p. 21); while substitute chemicals "cannot be produced or used as cheaply as DDT” (p. 23). In contrast to these problematizations, DDT's efficacy attracted far less attention and reports on resistance did not feature greatly. Table 5 provides illustrations of how each of the problematizations was countered in texts by Dr. Robert White-Stevens, who worked for American Cyanamid and whose texts serve as good examples because he "functioned more than anyone else as spokesman for the industry” (Coit Murphy, 2005: 95).

\section{—Table 5 about here-}

In defending the cognitive pillar and calling into question the factual basis of the problematizations, it became easier to defend the normative pillar: if there was no scientific basis for questioning its safety or necessity, then the use of DDT was entirely appropriate. Advocates for DDT also invoked ethical arguments to defend the normative pillar. Counter-texts employing utilitarian logic argued that, even if the existence of negative impacts on the environment or 
human health was accepted, they were small compared to the major benefits from using DDT. For example, malaria eradication rested "completely on its [DDT's] continued use” (World Health Organization Director-General Martin Candau in 1969, quoted in Sobelman, 1970: 365); and other horrible consequences would ensue if it were abandoned - “disease, epidemics, starvation, misery, and suffering” (Darby, 1962: 60).

Defense of the cognitive and normative pillars from the problematizations facilitated defense of the regulative pillar. After challenging the assertions and normative conclusions of DDT's opponents, counter-texts typically went on to argue that there was no case for abandoning DDT and certainly not through legal change.

[Opponents of a ban have cited] the record of safety that DDT has compiled throughout the years, and point to the negative findings of epidemiological and feeding studies carried out over the years on industrial workers and volunteers exposed to concentrated levels of DDT ... introduced expert testimony to the effect that DDT's chronic toxicity to man or animals has not been established by adequate proof ... contend[ed] that whatever harm to the environment that might be attributed to DDT, it results from misuse and overdosing that occurred in years past ... [and] attempted to prove that DDT is effective and that its use is more desirable than the organophosphates which are more acutely toxic and costly than DDT (Ruckelshaus, 1972: 13370).

In concluding our findings, we note that, despite counter-texts, certain problematizations promoted in Silent Spring survived the process of translation. The problematization of DDT's safety for the environment, i.e. assertions of negative impacts, became normalized in the discourse of DDT. The problematization of DDT's necessity also became normalized but in 
subverted form: it became widely accepted that DDT could be substituted for, but by other chemicals and not biological controls. The problematization of DDT's safety for humans survived, but in qualified form (i.e., as a possible threat); it was still being contested and had not been normalized. The problematization of efficacy was minimized in the debate over abandonment. As a result, the discourse changed and, by 1972, DDT was neither safe for the environment nor necessary. This change was sufficient to undermine the pillars that had previously held practices in place leading to voluntary and, later, coerced abandonment.

\section{A Model of Outsider-driven Deinstitutionalization}

In this section, we derive a series of propositions from our findings. We also discuss how outsider-driven deinstitutionalization compares with instances initiated by existing field members, by comparing our findings with those of other studies, including those of institutional change which, while not directly focusing on deinstitutionalization, nonetheless offer insights into how and why practices are abandoned.

Our study illustrates how - through a process of translating problematizations - the discourse about practices of DDT use changed, undermining institutional pillars and leading to the abandonment of those practices. In 1962, the discourse about DDT was relatively structured and coherent i.e., a more or less delimited set of field members produced texts that constructed practices of DDT use as safe, effective and necessary; and these meanings were widely shared and taken for granted. By 1972, however, the discourse had changed: it was no longer widely accepted that DDT was safe for the environment or necessary for insect control. Thus our first and overarching proposition is the following:

Proposition 1: In the case of outsider-driven deinstitutionalization, the abandonment of practices results from their problematization which, through a subsequent process of 
translation, changes the discourse about practices in ways that undermine the institutional pillars supporting them.

Our findings suggest that outsider-driven deinstitutionalization commences with “disruptive institutional work” which, argue Lawrence \& Suddaby (2006: 235), can have three aims: "undermining assumptions and beliefs" about practices; "disassociating moral foundations” from practices; and “disconnecting sanctions" from practices through changes in the legal or professional regulations. Our findings illustrate how this disruptive work is carried out i.e., through the authoring of texts that problematize existing practices in three specific ways designed to undermine each of the institutional pillars. In our case, texts asserted that DDT had negative impacts on human health and on the environment, thereby undermining existing assumptions and beliefs regarding the safety of DDT; categorized practices of DDT use as unethical, undesirable and inappropriate because it was not safe, thereby disassociating the use of DDT from its moral foundations; and called for legal restrictions to disconnect practices from the existing legislation that sanctioned the use of DDT.

Proposition 2: In the case of outsider-driven deinstitutionalization, disruptive institutional work is carried out through the authoring of texts that problematize practices by: (a) asserting negative impacts of practices; (b) categorizing practices as unethical, undesirable or inappropriate because of their negative impacts; and (c) calling for regulatory change to mitigate their negative impacts.

Our study thus contributes to the understanding of disruptive institutional work by illustrating how actors undermine assumptions and beliefs about practices; disassociate practices from their moral foundations; and disconnect practices from legal sanctions (Lawrence \& Suddaby, 2006) i.e., by authoring texts that problematize practices by associating them with 
negative impacts. Further, we can identify a number of differences in the ways that disruptive institutional work achieves these three aims in the case of outsider-driven deinstitutionalization by comparing our findings with studies of insider-driven deinstitutionalization.

First, in relation to undermining of assumptions and beliefs, our study suggests that in the case of outsider-driven deinstitutionalization, disruptive institutional work highlights the negative impacts of existing practices and, in so doing, increase the costs of continuing them, especially in relation to social costs. Hensman (2003: 363) found a similar situation in his study of the music industry where challengers originating from outside the field, such as Napster, tended to use arguments about justice - "notions of fairness and impartiality, democracy and equality" - to promote the abandonment of traditional practices of music distribution. In contrast, many studies of insider-driven deinstitutionalization have found that existing practices are abandoned primarily as a result of a growing awareness of economic advantages afforded by new practices (e.g., Greenwood et al., 2002; Leblebici et al., 1991; Lee \& Pennings, 2002; Thornton, 2002). So, for example, connect-time pricing was abandoned in the on-line database industry following changes in financial incentives that helped to overcome "the initial resistance of producers and users, who were worried that they would be worse off” (Farjoun, 2002: 863). Positive market feedback also encouraged Dutch accounting firms to abandon earlier forms of governance in favour of the partnership associate form (Lee \& Pennings, 2002).

Second, in relation to the disassociation of moral foundations, Lawrence \& Suddaby (2006) argue that insider-driven deinstitutionalization is typically carried out by the elite and most powerful members of the field. For example, leading accounting firms advocated new organizational forms in the Canadian accounting industry (Greenwood et al., 2002); the European Union’s Single Market Program was championed by its president (Fligstein, 2001); and chefs “in 
the centre of the French culinary world who had received honors from the French state and had garnered plaudits from the Guide Michelin” introduced nouvelle cuisine (Rao et al., 2003: 804). Further, these actors tend to promote "the gradual undermining of the moral foundations of institutions, rather than their wholesale turnover” (Lawrence \& Suddaby, 2006: 236; emphasis added) In contrast, our study suggests that when outsiders work to disassociate practices from their moral foundations, they do so through a direct attack. For example, as discussed in the findings, the identification of negative impacts associated with the continuation of existing practices of DDT use provided a powerful weapon with which to attack moral foundations directly. Furthermore, in the case of outsider-driven deinstitutionalization, elite actors in the field are often the target of such attacks. In our case, for example, the Department of Agriculture and the chemical industry were the subject of considerable criticism for continuing practices increasingly deemed to be unethical.

Third, in relation to disconnecting sanctions from practices, Lawrence \& Suddaby (2006) argue that insider-driven deinstitutionalization is also driven by field elites who can force regulatory bodies to act in accordance with their own ends, perhaps because they control sufficient resources to impose change (Dorado, 2005), or are of sufficient size and scope to evade formal regulation and can effectively make up their own rules. For example, Greenwood \& Suddaby (2006: 40) show how the major Canadian accounting firms were "too large to be effectively regulated by their profession.” In such a situation, it is conceivable that a single or small group of field members is able to bring about regulatory change and the abandonment of practices. In contrast, our findings suggest that outsider-driven deinstitutionalization requires a wider and heterogeneous set of actors to press for regulatory change before sanctions become disconnected from practices. 
Our study also suggests that, in the case of outsider-driven deinstitutionalization, disruptive institutional work originating from outside the field and promoting the abandonment of existing practices is met with a reaction by field members seeking to maintain the status quo. We define this reaction as "defensive institutional work" - the purposive action of individuals and organizations aimed at countering disruptive institutional work. In our case, certain actors - most notably in industry - sought to defend the pillars by producing their own texts countering assertions of negative impacts and the inappropriateness of practices, as well as the need for regulation. Our findings illustrate that defensive institutional work also takes the form of authoring texts but, instead of promoting problematizations, it disputes them in an attempt to legitimize existing practices, with an eye towards defending each of the institutional pillars.

Proposition 3: In the case of outsider-driven deinstitutionalization, defensive institutional work is carried out through the authoring of texts that contest problematizations of practices by: (a) countering assertions of negative impacts of practices; (b) countering categorizations of practices as unethical, undesirable or inappropriate; and (c) countering calls for regulatory change.

Defensive institutional work is an important new concept and contribution to the literature. We distinguish it from institutional work undertaken to "maintain" institutions, which is accomplished by actors "largely unaware of the original purpose, or ultimate outcome, of their actions" who engage "in the routines and rituals of reproduction" (Lawrence \& Suddaby, 2006: 234). In contrast, our study indicates that defensive institutional work is conscious and strategic and particularly relevant to outsider-driven deinstitutionalization because of the wholesale attack on the pillars supporting existing practices. We suggest that that the concept of defensive institutional work also applies to insider-driven deinstitutionalization, where a number of studies 
of institutional change have reported some form of resistance (e.g., Farjoun, 2002; Reay \& Hinings, 2005; Maguire \& Hardy, 2006). This concept is therefore important for understanding both the adoption of new practices as well as the abandonment of old ones because it focuses attention on the discursive struggle that is likely to ensue when insiders or outsiders seek changes in the practices in which existing field members' interests are vested; as well as on the specific ways field members respond to and resist initiatives for institutional change. More research is required, however, before we can draw firm conclusions about whether and how defensive institutional work in response to change driven by existing field members is similar to or different from that carried out to counter the change efforts of outsiders.

Disruptive institutional work results in an increase in the number and range of texts problematizing practices and contradicting previously widespread and taken for granted meanings; while defensive institutional work means that more counter-texts, seeking to defend existing meanings, circulate in the field. In this way, the ongoing process of translating problematizations serves to destabilize the existing discourse in two ways. First, the discourse about practices becomes less "structured" (Phillips et al., 2004), by which it is meant that texts are no longer produced only by actors in a delimited and predictable set of established subject positions, and they no longer draw on each other in well-established ways. Instead, texts that support and promote problematizations are produced by a range of new actors; counter-texts begin to be produced by existing actors; and the number of both problematizing texts and counter-texts increases. Second, as problematizations are reinterpreted in different ways and as problematizing texts and counter-texts contradict each other, the discourse about practices becomes less "coherent", by which it is meant that the discourse no longer presents a unified view of social reality (cf. Phillips et al., 2004). 
Proposition 4: In the case of outsider-driven deinstitutionalization, the process of translating problematizations leads to a loss of both (a) structure; and (b) coherence, in the discourse about practices.

Existing work has tended to examine how highly structured and coherent discourses hold institutions in place (e.g., Phillips et al., 2004). Our study extends this idea to suggest that outsider-driven deinstitutionalization relies on an initial breakdown in both the structure and coherence of the discourse in order for the possibilities for abandoning practices to become negotiable. In contrast, only a loss of coherence may be involved in some cases of insider-driven deinstitutionalization. For example, a study of institutional change in the Alberta health care system indicated a loss of coherence of the discourse as texts changed the focus on the "patient" to one on the "consumer” in advocating a “"consumer relationship’ as the appropriate model for providing health services”. However, these texts were produced by actors located in established subject positions, such as the government health department (Reay \& Hinings, 2005: 360).

The breakdown in the structure and coherence of the discourse occurs as practices are called into question. This means that practices are no longer taken for granted but this is unlikely to be sufficient to cause their abandonment. Our study indicates that outsider deinstitutionalization depends upon re-stabilization of the discourse in a changed form. Stabilization occurs through two mechanisms. First, new subject positions emerge in the discourse as new types of actors continue to engage in disruptive institutional work and the flow of texts problematizing practices from these new sources is maintained. Over time, these actors become widely recognized as having an interest in practices and accepted as legitimate contributors to the debate over them. Second, texts problematizing practices accumulate and problematizations become "normalized" i.e., taken for granted and constructed as “truth.” 
Proposition 5: In the case of outsider-driven deinstitutionalization, the discourse about practices is changed by the emergence of both (a) new subject positions, from which actors speak and act in support of problematizations; and (b) new bodies of knowledge, which normalize problematizations.

Our study suggests that outsider-driven deinstitutionalization requires the emergence of both new subject positions and new bodies of knowledge in the discourse about practices. First, new subject positions are necessary because outsiders are unlikely to have sufficient power in the field to successfully challenge insiders who defend existing practices. In our case, only as ecology and eco-toxicology became established as disciplines producing relevant knowledge about the impacts of practices of DDT use were scientists working in them able to challenge the traditional dominance of entomologists within the discourse of DDT. Similarly, recognition of the public's legitimate interest in practices of DDT and the taking up of their cause by environmental NGOs and politicians provided an effective challenge to industrial and agricultural lobbies. In fact, in the case of outsider-driven deinstitutionalization, some outsiders become insiders as the boundaries of the field are redrawn during the process: by 1972, for example, it was inconceivable that eco-toxicologists or environmental NGOs would be excluded from discussions of practices of using DDT and other pesticides. As Hensman (2003: 373) points out: the more successful the outsider is in securing the abandonment of practices, the more they "become what they disavow[ed]: dominant incumbents.” Furthermore, new bodies of knowledge must be constituted in which problematizations, in some form, are normalized (as with the problematization of DDT's safety for the environment in our case). Of course, this does not mean that all problematizations must survive the translation process or that those that do must survive in exactly their original form: they may be qualified (as with human safety); minimized (as with 
efficacy); or even subverted (as with necessity). If problematizations do not survive the translation process but are successfully refuted by counter-texts and disappear, deinstitutionalization will not occur and practices will not be abandoned.

In the case of insider-driven deinstitutionalization, it seems likely that new bodies of knowledge about existing practices will be required - field members are unlikely to abandon practices if their meaning does not change - but the emergence of new subject positions may not always be necessary. When field members promote change from established subject positions, there may be no need for new subject positions to emerge (e.g., Greenwood \& Suddaby, 2006; Thornton, 2002); in fact, dominant actors often initiate institutional change in order to protect their existing position (Hardy \& Maguire, 2008). Even when change has been initiated by peripheral groups, subject positions may not change radically. For example, in Leblebici's et al's (1991) study of the radio broadcasting industry, innovations by peripheral members of the field were appropriated by central members in order to retain their dominant position. On the other hand, some studies of insider-driven deinstitutionalization have indicated the emergence of new subject positions - such as the regional health authorities in the Alberta health care system (Reay \& Hinings, 2005). So, although the discourse was initially destabilized and its coherence reduced by actors proposing change from existing subject positions (i.e., the government health department), an important new subject position did eventually emerge - the regional health authority. Further research would be useful, therefore, to investigate the circumstances in which insider-driven deinstitutionalization involves the emergence of new subject positions.

As new subject positions emerge and problematizations are normalized in new bodies of knowledge - reconfiguring power/knowledge relations in the field - the discourse about practices is changed in ways that undermine institutional pillars. Our findings illustrate that, through a 
process of translating problematizations, new "facts" about negative impacts of practices undermine the cognitive pillar; new "opinions" regarding the appropriateness of practices undermine the normative pillar; and the new facts and opinions combine to provide government with a premise to make new formal "rules", undermining the regulative pillar.

Proposition 6: In the case of outsider-driven deinstitutionalization, the changes in the discourse about practices undermine the institutional pillars supporting practices, resulting in their abandonment.

Our study found evidence of both voluntary and coerced abandonment of practices as the discourse changed and suggests a temporal relationship between them. Early abandonment occurred as the cognitive and normative pillars were undermined; and it was voluntary. For example, most farmers producing food crops, for whom consumers' concerns about the safety of DDT residues were especially salient, abandoned DDT prior to 1972. As these markets dwindled, industry also engaged in voluntary abandonment of DDT: production was directed towards export markets; and, in the case of five manufacturers between 1965 and 1971, ceased completely (EPA, 1975), leaving only one domestic producer. Later, abandonment occurred through coercion as the regulative pillar was undermined: the ban forced cotton growers, the single remaining large market for DDT, to switch to substitutes.

\section{CONCLUSIONS}

Our first research question asked: what role does discourse play in outsider-driven deinstitutionalization? Our study answers this question by illustrating how changes in the discourse about practices of DDT use led to the abandonment of these practices. In 1962, the discourse about DDT was structured and coherent: it was widely taken for granted that DDT was safe, effective and necessary. By 1972, the meaning of practices of DDT use had changed: DDT 
was not considered safe for the environment or necessary for agriculture given available chemical substitutes. These problematizations had become normalized in new bodies of scientific, lay and legal knowledge that were supported and maintained as “truth” by actors speaking from powerful new subject positions in the discourse about DDT, undermining the institutional pillars supporting existing practices. As Foucault (1980: 131) has argued, truth is what a society "accepts and makes function as true” through "mechanisms and instances which enable one to distinguish true and false statements"; techniques and procedures that accord "value in the acquisition of truth"; and "the status of those who are charged with saying what counts as true".

To answer the second research question regarding the role of translation, we explored the specific form of problematizations that became accepted as new societal "truths". Two outcomes of the translation process were particularly important. First, the problematization of DDT's safety for the environment survived relatively intact i.e., assertions of the negative impacts of DDT on the environment became "facts", normalized in the discourse of DDT. Second, the problematization of DDT's necessity also became normalized but in subverted form, i.e. it became widely accepted that DDT could be substituted, but by other chemicals rather than the biological controls advocated in Silent Spring. It was the survival of these particular problematizations through the translation process, albeit in a different form from that promoted in Silent Spring that accounts for the abandonment of DDT.

To explain the abandonment of practices, researchers must therefore examine changes in the discourse about them and the fates of particular problematizations during the translation process. Our study illustrates these dynamics in the case of DDT and there is evidence to suggest that they also apply to other situations. For example, practices of chlorofluorocarbon use (CFCs) were abandoned as atmospheric scientists took up new subject positions in the field and as 
problematizations linking CFC use and ozone depletion became normalized (Levy, 1997). In contrast, if the discourse does not change and problematizations do not become normalized, practices are unlikely to be abandoned. For example, in the case of climate change, disruptive institutional work carried out by outsiders (e.g., Al Gore’s documentary, An Inconvenient Truth) has been met with counter-texts on the part of "climate change skeptics” who have sought "to attack the science” (Union of Concerned Scientists, 2008) and prevent the consensus that would see problematizations of current practices of energy production and use normalized in new bodies of knowledge. While the discourses of current practices of energy production and use have clearly lost coherence and structure as a result of the debate over climate change - practices are no longer taken for granted - there is as yet little evidence of widespread abandonment of current practices. This may be starting to change, however, with the UN's Intergovernmental Panel on Climate Change appearing to assume an important new subject position (winning the Nobel peace prize in 2007) in energy discourse and greater convergence in scientific reports linking climate change and man-made greenhouse gas emissions. We cannot assume, however, that discourses will necessarily re-stabilize within a given time frame. For example, the problematization of DDT's human safety continues to be contested (Rogan \& Chen, 2005), a situation which contributes to the continued use of DDT in malaria control practices in some countries (Maguire, 2008).

Our study also indicates how, in the case of outsider-driven deinstitutionalization, for practices to be abandoned the changed discourse must not only construct existing practices as inappropriate due to negative impacts; it must also construct alternative practices as acceptable. In our case, the subversion of the problematization of DDT's necessity played an important role in facilitating its abandonment. Had the question of DDT's necessity continued to be 
problematized in terms of biological controls as alternatives, the threat to industry would have been much greater and likely prompted more sustained defensive institutional work. Thus critics of practices need to be attentive to problematizations of necessity and how they are translated, i.e. not just to the ways in which existing practices are problematized, but also to how alternatives are discursively constructed. Our study therefore has important implications for the institutional literature that examines organizations and the natural environment: the transition to an ecologically sustainable economy can be usefully viewed as the deinstitutionalization of existing unsustainable or "brown" practices. For this to occur, disruptive institutional work must not only focus on the negative impacts of existing practices, but also on the acceptability of sustainable or "green” alternatives.

Our study also contributes to understanding the nature, role, and limits of agency in institutional change. The focus of much of the existing research is on "describing the characteristics of institutional logics and demonstrating their spread” through fields (Lawrence \& Suddaby, 2006: 245) and, as Zilber (2006: 300) notes, "research is still needed to explore the role of agency in translation.” We highlight the importance of authorial agency in deinstitutionalization by illustrating how disruptive institutional work is carried out through the production and distribution of texts that problematize practices. At the same time, by systematically tracking the process of translating problematizations after an intervention, we illustrate some of the limits to disruptive (and defensive) institutional work.

Whereas previous work has shown how actors can attempt to manage the meaning of practices by producing texts made persuasive through framing and rhetoric (Benford \& Snow, 2000; Suddaby \& Greenwood, 2005); our study indicates that, regardless of how persuasive a text is, actors cannot control whether or how other actors will translate their problematizations in 
subsequent texts. As a result, the translation process may result in a range of unintended outcomes. In our case, the problematization of efficacy was minimized - it failed to be normalized. The problematization of human safety did survive the process of translation but in highly qualified form (i.e., as a possible threat). In this way, the scope of problematizations may be minimized. Moreover, although Silent Spring problematized all chemical pesticides, as its problematizations were translated DDT was singled out for attention and evaluated in relation to chemical rather than biological alternatives. In this regard, the chemical industry may have lost the battle over DDT, but not the war over pesticides since chemicals continue to be extensively used for pest control today. It is also important to note, however, that the translation process can broaden the scope of problematizations: Silent Spring focused on pesticides, but also played an important role in galvanizing the wider environmental movement (Wright \& Welbourn, 2002).

Our study illustrates some of the limits to agency that arise from the process of translation: despite the attention that Silent Spring has attracted, our study indicates that that it did not single handedly lead to the abandonment of practices of DDT use. We suggest therefore that a single actor is unlikely to be responsible for the success of outsider-driven deinstitutionalization or of institutional entrepreneurship more generally (Garud, Hardy \& Maguire, 2007), despite the tendency to focus on the actions of particular "heroic” actors (Levy \& Sculley, 2007), and to "ignore the non-cooperative reactions of other members of the field” (Hardy \& Maguire, 2008: 210). Our study indicates that actors do disruptive and defensive institutional work strategically but, equally, institutional outcomes depend upon many actors other than the instigators of change.

By incorporating the sociology of translation into institutional theory (as advocated by Lawrence \& Suddaby, 2006), our study illustrates the precarious nature of problematizations as they are translated. Latour (1999: 15) has expressed concern that many contemporary studies 
informed by ANT have lost sight of the "series of transformations" that occur during translation and equate actor networks with "transport without deformation" and "an instantaneous, unmediated access to every piece of information”. By systematically tracking problematizations in texts associated with each of the institutional pillars over time and identifying different outcomes, our study also avoids the attribution of an overly strategic role to translators, who are sometimes "seen as Machiavellian manipulators who use every trick in the book to build alliances around their definitions of the world” (Denis, Langley \& Rouleau 2007: 184).

Another contribution stems from combining discourse and translation in a single study of institutional change. Translation lends itself to a textual approach - researchers acknowledge that the inscription of ideas in texts is the mechanism by which they travel in time and space (e.g. Czarniawska \& Joerges, 1996). Discourse theory thus complements and strengthens work based on the translation metaphor in a number of ways. First, it draws attention to how texts do not function individually or independently and, hence, emphasizes the importance of systematically studying bodies of texts. In this way, discourse theory provides the basis of a robust methodology with which to follow the process of translation i.e., by studying bodies of texts associated with each of the institutional pillars. Second, by emphasizing the production and distribution of texts as the mechanism through which discourses evolve and, as a result, change the ways in which people speak and act, discourse theory provides the basis for illustrating how actors can exercise agency i.e., by authoring texts to carry out disruptive and defensive institutional work. Third, by focusing on the consumption of texts, in addition to their production and distribution, it allows for interpretation i.e., the transformation of problematizations as meanings are negotiated between author and reader. In sum, by combining translation and discourse, we are better able to conceptualize and systematically investigate ongoing processes of translation through which 
problematizations are transformed in various ways as they travel through institutional fields, as well as the different outcomes from this process in terms of effects on discourse and, ultimately, on institutional practices.

Our study has a number of limitations. First, in using a single exploratory case study to build theory, generalizations must be drawn with care. We also recognize that our case is unusual in that a single text has been credited with "causing” the deinstitutionalization of DDT. This provided a methodological opportunity insofar as it gave us a feasible starting point for tracking how the problematizations in this particular text were translated - we could not possibly have investigated the translations of all the problematizations in all texts on DDT. But it did put us on a particular path - one that emanated from this particular text. Also, like Zilber (2006), we have focused our analysis on texts about practices rather than practices per se, as a result of which we are unable to offer any insights as to whether practices undergo similar translation processes.

In focusing on texts, we have had to make choices in selecting which texts to analyze. In some cases, e.g., the relevant legislation, the choice was relatively straightforward. In other cases, it was more complex. With reference to the normative pillar, we could only examine a selection of possible texts; and, even with scientific texts such as doctoral dissertations, scientific articles and textbooks, we could also only examine a small proportion of all the available texts, albeit one that we feel is representative of the larger scientific corpus. The choice of texts was probably most challenging in the case of counter-texts and, although we took steps to conduct a wide search to identify relevant texts, it is clear that we could only directly examine a small subset of the population of counter-texts. In addition, we rely on archival texts and, despite some interviews, were unable to complement our understanding with real-time data, which could be possible in a more contemporary case such as climate change. 
Another limitation of the study concerns our identification of the three problematizations in Silent Spring to be tracked through the translation process. Although informed by systematic coding, this analysis was necessarily interpretive. In effect, it was our translation of Carson's problematizations and a simplification of the complex arguments in the book.

Despite these limitations, there is considerable opportunity for future research to engage with and extend the contributions of this paper. One obvious avenue is the exploration of our propositions and assessment of whether or not they apply to other settings, and why. Our case concerns deinstitutionalization driven by environmental impacts and values; the environment plays a role in many contemporary problems, such as climate change, toxic pollution and declining biodiversity. These arenas are not only important ones for society generally, about which we therefore need to know more, but they also offer the opportunity for real time studies. There is also the opportunity to explore to what extent the model applies to situations where outsiders attempt to secure the abandonment of practices for purely economic reasons, such as when electronic firms attempted to redefine the field of photography in order to enter the industry (Munir, 2005). Is disruptive and defensive institutional work done in the same way as in our case in these situations and, if not, how and why does it differ? Other research settings that might prove interesting case studies for elaborating the discursive dynamics of institutional change are those where the science has been greatly contested. Examples might include attempts to ban smoking and the controversy over certain types of breast implants. In these situations, the "facts" are - or were - unclear and it seems likely that considerable defensive and disruptive institutional work was undertaken by different actors to influence the way in which research was carried out, interpreted and acted upon. Studies could also contemplate the failure of outsider-driven deinstitutionalization e.g., prohibition where attempts to legislate drinking practices out of 
existence failed - possibly because problematizations of liquor consumption were not normalized in the discourse about drinking. Future research could also focus on the systematic comparison of insider and outsider-driven deinstitutionalization. Work is also needed to ascertain in more detail the similarities and differences between these two forms of deinstitutionalization; as well as whether there are differences in institutional work when actors' primary aim is the problematization of existing practices compared to the promotion of new practices. Institutional change is an important research area for organization and management theory, and cases such as climate change and other environmental problems have significant implications for society, so a more complete understanding outsider-driven deinstitutionalization is vital. 


\section{References}

Agricultural Chemicals. June 1967. Agricultural chemicals forum: Part 1 persistent pesticides. 20-23

Ahmadjian, C. L. \& Robinson, P. 2001. Safety in numbers: Downsizing and the deinstitutionalization of permanent employment in Japan. Administrative Science Quarterly, 46(4): 622-36.

Ahmadjian, C. L. \& Robbins, G. E. 2005. A Clash of capitalisms: Foreign shareholders and corporate restructuring in 1990s Japan. American Sociological Review, 70(3): 451-471.

Anand, N. \& Peterson, R.A. 2002. When Market Information Constitutes Fields: Sensemaking of Markets in the Commercial Music Industry. Organization Science, 11(3): 270-284.

Barge, J. K. \& Oliver, C. 2003. Working with appreciation in managerial practice. Academy of Management Review, 28(1): 124-142.

Baldwin, I. L. 1962. Chemicals and pests. Science, 137(3535): 1042-1043.

Barley, S. R. \& Tolbert, P. S. 1997. Institutionalization and structuration: Studying the links between action and institution. Organization Studies, 18: 93-117.

Bartunek, J. M., Rynes, S. L. \& Ireland, R. D. 2006. What makes management research interesting, and why does it matter. Academy of Management Journal, 49(1):9-15.

Bean, W. B. 1963. The noise of Silent Spring. Archives of Internal Medicine, 114: 308-311.

Benford, R. D., \& Snow, D. 2000. Framing processes and social movements: An overview and assessment. Annual Review of Sociology, 26: 611-39

Blodgett, J. E. 1974. Pesticides: Regulation of an evolving technology. In S.SA. Epstein \& R.D. Grady (Eds.), Legislation of product safety: 197-287. Cambridge, MA: MIT Press.

Bosso, C. J. 1987. Pesticides and politics: The life cycle of a public issue, Pittsburgh, PA: University of Pittsburgh Press.

Bourdieu, P. 1990. The logic of practice (R. Nice, Trans.), Cambridge: Polity

Brown, S. D. 2002. Michel Serres: Science, Translation and the Logic of the Parasite Theory Culture \& Society, 19(3): 1-27

Callon, M. 1991. 'Techno-economic networks and irreversibility'. In J. Law (ed.) A sociology of monsters: Essays on power, technology and domination. London: Routledge, 132-161. 
Callon, M. 1986. Some elements of a sociology of translation: Domestication of the scallops and the fisherman of St. Briene Bay. In J. Law (ed.) Power, action and belief: A sociology of knowledge. London: Routledge, 1986.

Carabine, J. 2001. Unmarried motherhood 1830-1990: a genealogical analysis. In M. Wetherell, S. Taylor \& S. Yates (Eds), Discourse as data: a guide for analysts: 267-310. London: Sage.

Caronna, C. A. 2004. The misalignment of institutional "pillars": Consequences for the U.S. health care field. Journal of Health and Social Behavior, 45: 45-59.

Carson, R. 1962. Silent Spring. New York, NY: Houghton Mifflin.

CBS. 1963. The Silent Spring of Rachel Carson (video). New York, NY: CBS News Archives.

Coit Murphy, P. 2005. What a book can do: The publication and reception of Silent Spring, Amherst, MA: University of Massachusetts Press.

Colomy, P. 1998. Neofunctionalism and neoinstitutionalism: Human agency and interest ininstitutional change. Sociological Forum, 13(2): 265-300.

Covaleski, M. A., Dirsmith, M. W., Heian, J. B., \& Samuel, S. 1998. The calculated and the avowed: Techniques of discipline and struggles over identity in Big Six public accounting firms. Administrative Science Quarterly, 43: 293-327

Czarniawska, B. Forthcoming. Emerging institutions: Pyramids or anthills? Organization Studies, forthcoming.

Czarniawska, B. 1997. Narrating the organization: Dramas of institutional identity. Chicago: The University of Chicago Press.

Czarniawska, B. \& Joerges, B. 1996. Travel of ideas. In B. Czarniawska \& G. Sevon (Eds.), Translating organizational change: 13-48. Berlin: De Gruyter.

Czarniawska, B. \& Sevón, G. 1996. Introduction, 1-12 In B. Czarniawska \& G. Sevón (Eds.), Translating organizational change: 13-48. Berlin: De Gruyter 1996.

Darby, W. J. 1962. Silence, Miss Carson. Chemical \& Engineering News, October 1: 60-63.

Davis, G. F. Diekmann, K. A. \& Tinsley, C. H. 1994. The decline and fall of the conglomerate firm in the 1980s: The deinstitutionalization of an organizational form. American Sociological Review, 59(4): 547-570.

Denis, J. L., Langley, A. \& Rouleau, L. 2007. Strategizing in pluralistic contexts: Rethinking theoretical frames. Human Relations, 60(1): 179-215. 
Dorado, S. 2005. Institutional entrepreneurship, partaking, and convening. Organization Studies, 26(3): 385-414.

Douglas, M. 1986. How institutions think, New York: Syracuse University Press.

Du Gay, P. 1996. Consumption and identity at work, London: Sage.

Dunlap, T. R. 1981. DDT: Scientists, citizens and public policy, Princeton, NJ: Princeton University Press.

Dyer, W. B. Jr. \& Wilkins, A. L. 1991. Better stories, not better constructs, to generate better theory: A rejoinder to Eisenhardt, Academy of Management Review, 16(3): 613-619.

Eisenhardt, K. M. 1989. Building theories from case study research. Academy of Management Review, 14: 532-550.

Eisenhardt, K. M. \& Bourgeois, L. J. 1988. Politics of strategic decision making in high-velocity environments: Toward a midrange theory. Academy of Management Journal, 31: 737770 .

EPA. 1975. DDT: A review of scientific and economic aspects of the decision to ban its use as a pesticide, Washington, DC: Environmental Protection Agency (EPA-540/1-75-022).

Farjoun, M. 2002. The dialectics of institutional development in emerging and turbulent fields: The history of pricing conventions in the on-line database industry. Academy of Management Journal, 45(5): 848-874.

Foucault, M. 1979. Discipline and punish. Harmondsworth: Penguin.

Foucault, M. 1980. Power/Knowledge: Selected interviews and other writings 1972-1977. Brighton: Harvester Press.

Fligstein, N. 2001. Social skill and the theory of fields. Sociological Theory, 19(2): 105-125

Garud, R., Hardy, C. \& Maguire, S. 2007. Institutional entrepreneurship as embedded agency: An introduction to the special issue. Organization Studies, 28(7): 1055-1077.

Greenwood, R. \& Suddaby, R. 2006. Institutional entrepreneurship in mature fields: The big five accounting firms. Academy of Management Journal, 49(1): 27-48.

Greenwood, R., Suddaby, R. \& Hinings, C. R. 2002. The role of professional associations in institutional change. Academy of Management Journal, 45: 58-80.

Hall, S. 2001. Foucault: Power, knowledge and discourse. In M. Wetherell, S. Taylor \& S. Yates (Eds.), Discourse theory and practice: A reader: 72-81. London: Sage. 
Hardy, C. \& Phillips, N. 2004. Discourse and power. In D. Grant, C. Hardy, C. Oswick \& L. Putnam (Eds.), Handbook of Organizational Discourse: 219-318. London: Sage.

Hardy, C., Lawrence, T. B. \& Grant, D. 2005. Discourse and collaboration: The role of conversations and collective identity. Academy of Management Review, 30(1): 1-20.

Hardy, C. \& Maguire, S., 2008. Institutional Entrepreneurship. In R. Greenwood, C. Oliver, R. Suddaby \& K. Sahlin-Andersen (Eds.), Handbook of Organizational Institutionalism: 198-217. London: Sage.

Hargadon, A. \& Douglas, Y. 2001. When innovations meet institutions: Edison and the design of the electric light. Administrative Science Quarterly, 46: 476-501.

Hensman, M. 2003. Social movement organizations: A metaphor for strategic actors in institutional field. Organization Studies, 24(3): 355-381.

Henkin, H., Merta, M.and Staples, J. 1971. The environment, the establishment, and the law New York: Houghton Mifflin Company.

Heracleous, L. \& Barrett, M. 2001. Organizational change as discourse: Communicative actions and deep structures in the context of information technology implementation. Academy of Management Journal, 44(4): 755-778.

Hoffman, A. J. 1999. Institutional evolution and change: Environmentalism and the U.S. chemical industry. Academy of Management Journal, 42: 351-371.

Hoffman, A. J., Riley, H. C., Troast J. G. Jr. \& Bazerman, M. H. 2002. Cognitive and institutional barriers to new forms of cooperation on environmental protection: Insights from Project XL and Habitat Conservation Plans. The American Behavioral Scientist, 45(5): 820-845.

Jepperson, R. L. 1991. Institutions, institutional effects, and institutionalism. In W.W. Powell \& P.J. DiMaggio (Eds.), The new institutionalism in organizational analysis, 143-163. Chicago, IL: University of Chicago Press.

Knights, D. 1992. Changing spaces: the disruptive impact of new epistemological location for the study of management. Academy of Management Review, 17(3): 514-36.

Knights, D \& Morgan, G. 1991. Strategic discourse and subjectivity: towards a critical analysis of corporate strategy in organizations. Organization Studies, 12(3): 251-273.

Kudlinski, K. V. 1988. Rachel Carson: Pioneer of ecology, New York: Puffin.

Latour, B. 1986. The powers of association. In J. Law (Ed.), Power, action and belief: London: Routledge \& Kegan Paul: 264-280. 
Latour, B. 1999. On recalling ANT. In L. Law and Hassard, J. (eds.) Actor network theory and after. Oxford: Blackwell, 15-25

Lawrence, T. \& Suddaby, R. 2006. Institutions and institutional work. In S.R. Clegg, C. Hardy, T.B. Lawrence \& W.R. Nord (Eds.), Handbook of Organization Studies: 215-254. London: Sage.

Lawrence, T., Winn, M. I. \& Jennings, P. D. 2001. The temporal dynamics of institutionalization. Academy of Management Review, 26: 624-644.

Lear, L. 1997. Rachel Carson: Witness for nature, New York, NY: Henry Holt \& Company.

Leblebic, H. Salancik, G. Copay, A. \& King, T. 1991. Institutional change and the transformation of interorganizational fields: An organizational history of the US radio broadcasting industry. Administrative Science Quarterly, 36(3): 333-363.

Lee, K. \& Pennings, J. M. 2002. Mimicry and the market: Adoption of a new organizational form. Academy of Management Journal, 45(1): 144-162.

Levy, D. 1997. Business and international environmental treaties: Ozone depletion and climate change. California Management Review, 39(3): 54-71.

Levy, D. \& Scully, M. 2007. The institutional entrepreneur as modern prince: The strategic face of power in contested fields. Organization Studies, 28(7): 971-991.

Lewis, J. 1985. The Birth of EPA. EPA Journal, 11(9) [retrieved online on 20060706 from: http://www.epa.gov/history/topics/epa/15c.htm]

Long, R. K. Jr. 1962. Letter to editor, Audubon Magazine, 64 (Nov.-Dec. 1962): 299.

Maguire, S. 2004. The Coevolution of technology and discourse: A study of substitution processes for the insecticide DDT. Organization Studies, 25(1): 113-134.

Maguire, S. 2008 (forthcoming). Contested icons: Rachel Carson and DDT. In L. Sideris and K.D. Moore, K.D. (Eds.), On Nature's Terms: the Legacy and Challenge of Rachel Carson: XxX-Xxx. New York, NY: SUNY Press.

Maguire, S. \& Hardy, C. 2006. The emergence of new global institutions: A discursive perspective. Organization Studies, (27)1: 7-29.

Maguire, S., Hardy, C. \& Lawrence, T. 2004. Institutional entrepreneurship in emerging fields: HIV/AIDS treatment advocacy in Canada. Academy of Management Journal, 47(5): 657-679. 
McAdam D., McCarthy J. D. \& Zald, M. N. (eds.) 1996. Comparative perspectives on social movements: Opportunities, mobilizing structures, and framing. Cambridge, UK: Cambridge University Press.

Meriläinen, S., Tienari, J., Thomas, R. \& Davies, A. 2004. Management consultant talk: A crosscultural comparison of normalizing discourse and resistance. Organization, 11(4), 539564.

Mrak, E. 1969. Report of the secretary's commission on pesticides and their relationship to environmental health - Parts I and II, Washington, DC: HEW.

Monsanto 1962. The desolate year. Monsanto Magazine, October, 1962: 4-9.

Munir, K. A. 2005. The social construction of events: A study of institutional change in the photographic field. Organization Studies, 26(1): 93-112.

NACA 1962. Fact and fancy, Washington: National Agricultural Chemicals Association.

Oakes, L. S., Townley, B. \& Cooper, D .J. 1998. Business planning as pedagogy: Language and control in a changing institutional field. Administrative Science Quarterly, 43: 257-292.

Odum, P. 1959. Fundamentals of ecology, $2^{\text {nd }}$ Edition. Philadelphia, PA: Saunders.

Odum, P. 1971. Fundamentals of ecology, $3^{\text {rd }}$ Edition. Philadelphia, PA: Saunders.

Oliver, C. 1992. The antecedents of deinstitutionalization. Organization Studies, 13: 563-588.

Parker, I. 1992. Discourse dynamics: Critical analysis for social and individual psychology, London: Routledge.

Pettigrew, A. M. 1979. On studying organizational cultures. Administrative Science Quarterly, 24: 57-81.

Pfadt, R. E. 1962. Fundamentals of applied entomology, $1^{\text {st }}$ Edition. New York, NY: Macmillan.

Pfadt, R. E. 1971. Fundamentals of applied entomology, $2^{\text {nd }}$ Edition. New York, NY: Macmillan.

Phillips, N., Lawrence, T. \& Hardy, C. 2004. Discourse and institutions. Academy of Management Review, 29/4: 1-18.

Potter, J. \& Wetherell, M. 1987. Discourse and social psychology: Beyond attitudes and behavior, London: Sage.

PSAC 1963. The use of pesticides - President's sScience advisory committee report, Washington, DC: Government Printing Office. 
Rao, H., Monin, P. \& Durand, R. 2003. Institutional change in Toque Ville: Nouvelle cuisine as an identity movement in French gastronomy. American Journal of Sociology, 108: 795843.

Reay, T. \& Hinings, C. R. 2005. The recomposition of an organizational field: Health care in Alberta. Organization Studies, (26)3: 351-384.

Reed, M. 1998. Organizational analysis as discourse analysis: A critique. In D. Grant \& C. Oswick (Eds.), Discourse and organization: 193-213. London: Sage.

Ribicoff, A. 1966. Pesticides and public policy, Report of the Committee on Government Operations, U.S. Senate, 89th Congress, 2nd session, report 1379, Washington, DC: US Government Printing Office.

Rogan, W. J. \& Chen, A. 2005. Health risks and benefits of bis(4-chorophenyl)-1,1,1trichloroethane (DDT). Lancet, 366: 763-773.

Ruckelshaus, W. D. 1970. First Administrator on establishment of EPA (press release: Dec. 16, 1970), Washington, DC: EPA.

Ruckelshaus, W. D. 1972. Consolidated DDT hearings: Opinion and order of the administrator. Federal Register, 37(1331,Friday, July 7, 1972): 13369-13376.

Scott, W. R. 2001. Institutions and organizations, $2^{\text {nd }}$ Edition. Thousand Oaks, CA: Sage.

Smith, D. E. 1990. Texts, facts, and femininity: Exploring the relations of ruling, New York: Routledge.

Sobelman, M. (Ed.) 1970. Selected statements from state of Washington DDT hearings held in Seattle October 14, 15, 16, 1969 and other related paper. Torrance, CA: DDT Producers of the United States.

Steinberg, M. W. 1999. The talk and back talk of collective action: A dialogic analysis of repertoires of discourse among Nineteenth Century British Cotton Spinners. American Journal of Sociology, (105)3: 736-780.

Suddaby, R. \& Greenwood, R. 2005. Rhetorical strategies of legitimacy Administrative Science Quarterly, 50(1): 35-68.

Taylor, J. R., Cooren, F., Giroux, N. \& Robichaud, D. 1996. The communicational basis of organization: Between the conversation and the text. Communication Theory, 6(1): 1-39.

Thornton P. H. 2002. The rise of the corporation in a craft industry: Conflict and conformity in institutional logics. Academy of Management Journal, 45(1): 81-101. 
Time. 1968. Pesticides the price for progress. September 28: 45-48.

Townley, B. 1993. Foucault, power/knowledge and its relevance for human resource management. Academy of Management Review, 18(3): 518-545.

Union of Concerned Scientists 2008. The science of global warming [retrieved online on 2008 0109 from http://www.ucsusa.org/global_warming/science/science-of-globalwarming.html].

Van de Ven, A. H. \& Poole, M. S. 1990. Methods for studying innovation development in the Minnesota innovation research program. Organization Science, 1(3): 313-334.

White-Stevens, R. H. 1962a. Faddists hampering progress. Agricultural Chemicals, September: 28, 32, 111.

White-Stevens, R. H. 1962b. Communications create understanding. Agricultural Chemicals, October: 34-36, 81-83.

White-Stevens, R. H. 1969a. The case for DDT. In M. Sobelman (Ed.), 1970. Selected statements from state of Washington DDT Hearings held in Seattle October 14, 15, 16, 1969 and other related papers: 345. Torrance, CA: DDT Producers of the United States.

White-Stevens, R. H. 1969b. The economic and environmental impact of pesticides. In M. Sobelman (Ed.), 1970. Selected statements from state of Washington DDT Hearings held in Seattle October 14, 15, 16, 1969 and other related papers: 346-364. Torrance, CA: DDT Producers of the United States.

White-Stevens, R. H. 1970. DDT ban: A judgment of emotion and mystique. Science, 170(3961): 928

White-Stevens, R. H. 1972. A perspective on pesticides. USGA Green Section Record, 10(4): $17-21$.

Whitten, J. L. 1966. That we may live, New York, NY: Van Nostrand.

Wicks, D. 2001. Institutionalized mindsets of invulnerability: Differentiated institutional fields and the antecedents of organizational crisis. Organization Studies, 22(4): 659-692.

Wilson, 2002. Afterword. In Carson, R. Silent Spring: 357-363. New York: Houghton Mifflin.

Wright, D. A. \& Welbourne, P. 2002. Environmental toxicology, Cambridge: Cambridge University Press.

Yin, R. K. 2003. Case study research: Design \& methods, $3^{\text {rd }}$ Edition. Thousand Oaks: Sage. 
Zilber, T. B. 2002. Institutionalization as an interplay between actions, meanings and actors: The case of a rape crisis center in Israel. Academy of Management Journal, 45(1): 234-254.

Zilber, T. B. 2006. The work of the symbolic in institutional processes: Translations of rational myths in Israeli hi-tech. Academy Management Journal, 49(2): 281-303. 
Table 1a: Comparison of Editions of Applied Entomology Textbook available in 1962 and 1972

\begin{tabular}{|c|c|c|}
\hline Pfadt, 1962 ( $1^{\text {st }}$ edition $)$ & Pfadt, 1971 ( $2^{\text {nd }}$ edition $)$ & Significance \\
\hline $\begin{array}{l}\text { "There are several } \\
\text { advantages and a few } \\
\text { disadvantages in using } \\
\text { DDT. ... It acts as both a } \\
\text { contact and stomach poison } \\
\text { and is stable under most } \\
\text { conditions. Its residual } \\
\text { action is usually an } \\
\text { advantage, but may also be } \\
\text { a disadvantage when it gets } \\
\text { into food products." (183) }\end{array}$ & $\begin{array}{l}\text { "DDT is a stable product which does not } \\
\text { break down readily and thus tends to } \\
\text { remain in the environment. It is highly } \\
\text { insoluble in water and does not leach to } \\
\text { any extent from the soil. It accumulates } \\
\text { in fat and thus becomes stored in the } \\
\text { bodies of animals. This latter fact has } \\
\text { been the prime reason for the several } \\
\text { cases of banning of DDT. Organisms in } \\
\text { the food chain accumulate DDT and } \\
\text { pass it on to their consumers. The } \\
\text { increase in chemical concentration as it } \\
\text { passes through the food chain is called } \\
\text { biological magnification." (208) }\end{array}$ & $\begin{array}{l}\text { Evidence that problematization } \\
\text { of environmental safety } \\
\text { survives the translation } \\
\text { process: the "few } \\
\text { disadvantages" described in } \\
1962 \text { affect farmers only, } \\
\text { whereas a longer list of } \\
\text { problems is described in } 1971 \\
\text { and these affect the } \\
\text { environment, i.e. persistence in } \\
\text { soil, accumulation in animals, } \\
\text { and biological magnification } \\
\text { via food chains }\end{array}$ \\
\hline $\begin{array}{l}\text { "DDT is a relatively safe } \\
\text { insecticide." (183) }\end{array}$ & $\begin{array}{l}\text { "[DDT] has relatively little acute } \\
\text { toxicity to mammals. But there is } \\
\text { concern about possible chronic effects } \\
\text { in mammals exposed to low levels of } \\
\text { DDT over a long period of time.” (208) }\end{array}$ & $\begin{array}{l}\text { Evidence that problematization } \\
\text { of human safety survives the } \\
\text { translation process but in } \\
\text { qualified form: human safety } \\
\text { is parsed into acute and } \\
\text { chronic toxicity and the latter } \\
\text { is "possible" }\end{array}$ \\
\hline $\begin{array}{l}\text { Resistance is addressed in } \\
\text { one paragraph with specific } \\
\text { mention of organochlorines } \\
\text { (including DDT); } 12 \text { insects } \\
\text { with resistance are } \\
\text { enumerated (323); “[DDT] } \\
\text { is effective against a wide } \\
\text { range of insects, but several } \\
\text { species have developed } \\
\text { resistance to it.” (183) }\end{array}$ & $\begin{array}{l}\text { Resistance is addressed in one } \\
\text { paragraph with specific mention of } \\
\text { organochlorines (including DDT); } 16 \\
\text { insects with resistance are enumerated; } \\
\text { "entomologists have now found } \\
\text { resistance in } 20 \text { species ... mainly to } \\
\text { chlorinated hydrocarbon insecticides } \\
\text { [which includes DDT]”; There is } \\
\text { specific mention of resistance to DDT in } \\
\text { the bollworm; "Resistance of the } \\
\text { majority of these species is limited to } \\
\text { relatively small areas. No species is } \\
\text { known to be resistant throughout its } \\
\text { entire distribution.” (349 \& 352) }\end{array}$ & $\begin{array}{l}\text { Evidence that problematization } \\
\text { of efficacy survives the } \\
\text { translation process but in } \\
\text { minimized form: resistance is } \\
\text { acknowledged in } 1962 \text { and has } \\
\text { increased somewhat by } 1972 \text {, } \\
\text { but limits are put on its scale } \\
\text { and scope }\end{array}$ \\
\hline $\begin{array}{l}\text { Biological controls are } \\
\text { addressed in approximately } \\
\text { four pages (excluding } \\
\text { photos); chemical controls } \\
\text { are addressed in a chapter of } \\
32 \text { pages. }\end{array}$ & $\begin{array}{l}\text { Biological controls are addressed in } \\
\text { approximately three pages (excluding } \\
\text { photos); chemical controls are addressed } \\
\text { in a chapter of } 29 \text { pages. }\end{array}$ & $\begin{array}{l}\text { No evidence that } \\
\text { problematization of necessity } \\
\text { has survived translation: } \\
\text { coverage of biological and } \\
\text { chemical controls is similar in } \\
\text { both editions, with limited } \\
\text { coverage of biological controls }\end{array}$ \\
\hline
\end{tabular}


Table 1b: Comparison of Editions of Ecology Textbook available in 1962 and 1972

\begin{tabular}{|c|c|c|}
\hline $\begin{array}{c}\text { Odum, } 1959\left(2^{\text {nd }}\right. \\
\text { edition })\end{array}$ & Odum, 1971 ( $3^{\text {rd }}$ edition) & Significance \\
\hline $\begin{array}{l}\text { "DDT, ecology of" is } \\
\text { the only entry in the } \\
\text { index and is indexed to } \\
\text { two pages (530). }\end{array}$ & $\begin{array}{l}\text { "DDT, in food chains" is indexed to two } \\
\text { pages; "DDT, poisoning of birds by" is } \\
\text { indexed to one page; "DDT, worldwide } \\
\text { pollution by" is indexed to one page } \\
\text { (561). }\end{array}$ & $\begin{array}{l}\text { Evidence that problematization } \\
\text { of environmental safety } \\
\text { survives translation: } \\
\text { - DDT's presence in food chains } \\
\text { and poisoning of birds is } \\
\text { highlighted in the index }\end{array}$ \\
\hline $\begin{array}{l}\text { There is no reference to } \\
\text { Silent Spring which had } \\
\text { yet to be written }\end{array}$ & $\begin{array}{l}\text { “... and the poisoning of entire food } \\
\text { chains was dramatically brought to } \\
\text { public attention in } 1962 \text { by Rachel } \\
\text { Carson's famous book, Silent Spring." } \\
\text { (445); “The end result of the widespread } \\
\text { use of DDT is that whole populations of } \\
\text { predatory birds ... are being wiped out” } \\
\text { (75) }\end{array}$ & $\begin{array}{l}\text { The “poisoning of entire food } \\
\text { chains” is asserted without } \\
\text { qualification, with explicit } \\
\text { reference to Silent Spring. } \\
\text { - DDT’s negative impacts on } \\
\text { bird populations are asserted } \\
\text { without qualification. }\end{array}$ \\
\hline $\begin{array}{l}\text { Environmental pollution } \\
\text { is one paragraph ( } 425- \\
426) \text {. }\end{array}$ & $\begin{array}{l}\text { Environmental pollution is addressed in } \\
\text { a new, dedicated chapter of } 18 \text { pages } \\
\text { (432-450); within it, the "Insecticides" } \\
\text { section is entirely devoted to DDT and } \\
\text { other organochlorine insecticides with } \\
\text { following assertion: "these substances } \\
\text { have produced one of the world's most } \\
\text { serious pollution problems" (446) }\end{array}$ & $\begin{array}{l}\text { A new chapter places particular } \\
\text { emphasis on DDT and other } \\
\text { persistent insecticides the } \\
\text { negative impacts of which are } \\
\text { accepted without qualification } \\
\text { and characterized as "one of the } \\
\text { world's most serious pollution } \\
\text { problems" }\end{array}$ \\
\hline $\begin{array}{l}\text { There is no mention of } \\
\text { human safety in } \\
\text { discussions of DDT and } \\
\text { other pesticides. }\end{array}$ & $\begin{array}{l}\text { "While direct effects [of DDT and other } \\
\text { organochlorines] on the hormone } \\
\text { balance in man have not yet been } \\
\text { demonstrated, concentration levels in } \\
\text { human tissue are now high enough that } \\
\text { such effects, and also cancer and } \\
\text { deleterious mutuations, could occur in } \\
\text { the future (446, emphasis in original). }\end{array}$ & $\begin{array}{l}\text { Evidence that problematization } \\
\text { of human safety survives } \\
\text { translation in qualified form: } \\
\text { potential threat is acknowledged } \\
\text { but more research is needed }\end{array}$ \\
\hline $\begin{array}{l}\text { “... excessive use of } \\
\text { insecticides is creating } \\
\text { other problems such as } \\
\ldots . \text { the development of } \\
\text { resistance in pests } \\
\text { themselves.” (426) }\end{array}$ & $\begin{array}{l}\text { "Unheeded warnings of an } \\
\text { entomological backlash (i.e. pest } \\
\text { outbreaks) actually induced by spraying } \\
\text { were voiced in the 1950s" (445). }\end{array}$ & $\begin{array}{l}\text { Evidence that problematization } \\
\text { of efficacy survives translation } \\
\text { but in minimized form: } \\
\text { resistance is described in both } \\
\text { editions but in passing reference } \\
\text { only }\end{array}$ \\
\hline $\begin{array}{l}\text { Biological control of } \\
\text { insects is indexed to two } \\
\text { pages (527). }\end{array}$ & $\begin{array}{l}\text { Biological control of pests is indexed to } \\
\text { two pages (559). }\end{array}$ & $\begin{array}{l}\text { No evidence that } \\
\text { problematization of necessity } \\
\text { survives translation: limited } \\
\text { coverage of biological controls } \\
\text { in both editions. }\end{array}$ \\
\hline
\end{tabular}


Table 2: Comparison of New York Times Editorials 1962-1972

\begin{tabular}{|c|c|c|c|c|c|}
\hline $\begin{array}{l}\text { Date and page } \\
\text { of editorial }\end{array}$ & $\begin{array}{l}\text { DDT's safety for } \\
\text { environment is } \\
\text { questioned? }\end{array}$ & $\begin{array}{l}\text { DDT's safety for humans } \\
\text { is questioned? }\end{array}$ & $\begin{array}{l}\text { DDT's efficacy is } \\
\text { questioned? }\end{array}$ & DDT's necessity is questioned? & $\begin{array}{c}\text { More } \\
\text { regulation is } \\
\text { recommended? }\end{array}$ \\
\hline Jul 2 1962: 28 & & & & & Yes \\
\hline May 17 1963: 32 & Yes & Yes & & & Yes \\
\hline May 27 1964: 38 & Yes & & & $\begin{array}{l}\text { Yes: safer chemical substitutes } \\
\text { are available }\end{array}$ & Yes \\
\hline Apr 27 1965: 36 & Yes & & & $\begin{array}{l}\text { Yes: biological controls can be } \\
\text { developed }\end{array}$ & \\
\hline Jan 24 1969: 46 & Yes & & & & Yes \\
\hline $\begin{array}{l}\text { Apr } 20 \text { 1969: } \\
\text { E12 }\end{array}$ & Yes & & & $\begin{array}{l}\text { Yes: safer chemical substitutes } \\
\text { are available }\end{array}$ & Yes \\
\hline May 3 1969: 34 & Yes & Yes, possible threat exists & & & Yes \\
\hline $\begin{array}{l}\text { May } 25 \text { 1969: } \\
\text { E16 }\end{array}$ & Yes & & & & Yes \\
\hline Jun 2 1969: 44 & Yes & Yes, possible threat exists & & $\begin{array}{l}\text { Yes: safer chemical substitutes } \\
\text { are available }\end{array}$ & Yes \\
\hline Jul 7 1969: 32 & Yes & Yes, possible threat exists & Yes & & Yes \\
\hline Nov 29 1969: 32 & Yes & & & & Yes \\
\hline Feb 17 1970: 42 & Yes & & & & Yes \\
\hline Jun 23 1970: 42 & Yes & & & & Yes \\
\hline Jul 3 1970: 24 & Yes & Yes & & & Yes \\
\hline $\begin{array}{l}\text { Aug } 23 \text { 1970: } \\
\text { E12 }\end{array}$ & Yes & & & $\begin{array}{l}\text { Yes: but there is a need for cost- } \\
\text { effective chemical substitutes and } \\
\text { biological controls }\end{array}$ & Yes \\
\hline Nov 26 1971: 36 & Yes & Yes, possible threat exists & Yes & $\begin{array}{l}\text { Yes: but there is a need for } \\
\text { biological controls }\end{array}$ & Yes \\
\hline Jun 18 1972: E5 & Yes & Yes, possible threat exists & & & Yes \\
\hline Significance & $\begin{array}{l}\text { Evidence that } \\
\text { problematization of } \\
\text { environmental } \\
\text { safety is taken up } \\
\text { during the process of } \\
\text { translation }\end{array}$ & $\begin{array}{l}\text { Evidence that } \\
\text { problematization of } \\
\text { human safety is qualified } \\
\text { during the process of } \\
\text { translation: "possible" } \\
\text { threat exists }\end{array}$ & $\begin{array}{l}\text { Little evidence that } \\
\text { problematization of } \\
\text { efficacy is of concern or } \\
\text { taken up during the } \\
\text { process of translation }\end{array}$ & $\begin{array}{l}\text { Evidence that problematization of } \\
\text { necessity is subverted during the } \\
\text { process of translation: other } \\
\text { chemicals are seen as acceptable } \\
\text { substitutes }\end{array}$ & $\begin{array}{l}\text { Consistent call } \\
\text { for more } \\
\text { regulation }\end{array}$ \\
\hline
\end{tabular}


Table 3: Comparison of Government Advisory Reports

\begin{tabular}{|c|c|c|c|}
\hline PSAC Report (1963) & Ribicoff Report (1966) & Mrak Report (1969) & Significance \\
\hline $\begin{array}{l}\text { The committee recognizes "the } \\
\text { wide distribution and persistence } \\
\text { of DDT" (5); "Mortalities among } \\
\text { birds have approached } 80 \text { percent } \\
\text { in areas heavily treated with DDT } \\
\text {... Fish losses have been } \\
\text { extensive ... using DDT.” (10) }\end{array}$ & $\begin{array}{l}\text { Carson is mentioned re safety for } \\
\text { environment (1); there is } \\
\text { acknowledgement that "birds die from } \\
\text { eating pesticide-contaminated } \\
\text { earthworms" (24) and "too often we } \\
\text { alter the environment [with pesticides] } \\
\text { before we understand what is going } \\
\text { on." (25) }\end{array}$ & $\begin{array}{l}\text { "Abundant evidence proves the } \\
\text { widespread distribution of DDT ... in } \\
\text { man, birds, fish, other aquatic } \\
\text { organisms, wildlife... Evidence also } \\
\text { demonstrates that these materials are } \\
\text { highly injurious to some nontarget } \\
\text { species and threaten other species and } \\
\text { biological systems." (9) }\end{array}$ & $\begin{array}{l}\text { Evidence that problematization of } \\
\text { environmental safety is taken up } \\
\text { during the process of translation } \\
\text { (although Ribicoff Report is more } \\
\text { cautious): negative impacts of DDT } \\
\text { on the environment are asserted. }\end{array}$ \\
\hline $\begin{array}{l}\text { Carson is mentioned re safety for } \\
\text { humans (23); but “[DDT’s] } \\
\text { toxicity to man is low” with “no } \\
\text { evidence of tumor induction” } \\
\text { (12). But “possible long-term } \\
\text { effects cannot be predicted” (9) }\end{array}$ & $\begin{array}{l}\text { "While [chronic toxicity] experiments } \\
\text { to date have detected no adverse } \\
\text { effects the evidence is not yet } \\
\text { sufficient for final judgment." (23) }\end{array}$ & $\begin{array}{l}\text { DDT is "positive for tumorigenicity", } \\
\text { however "DDT can be regarded } \\
\text { neither as a proven danger as a } \\
\text { carcinogen for man nor as an } \\
\text { assuredly safe pesticide."(471) }\end{array}$ & $\begin{array}{l}\text { Evidence that problematization of } \\
\text { human safety is qualified during } \\
\text { the process of translation: negative } \\
\text { impacts of DDT are regarded as not } \\
\text { proven, but neither is its safety. }\end{array}$ \\
\hline $\begin{array}{l}\text { Resistance is addressed in two } \\
\text { sentences in the } 25 \text { page report. }\end{array}$ & $\begin{array}{l}\text { Resistance is addressed in two } \\
\text { paragraphs in the } 86 \text { page report }\end{array}$ & $\begin{array}{l}\text { Resistance is mentioned in passing as } \\
\text { "having a growing influence on the } \\
\text { use of pesticides" (22) }\end{array}$ & $\begin{array}{l}\text { Evidence that problematization of } \\
\text { efficacy is minimized during the } \\
\text { process of translation: resistance is } \\
\text { mentioned only briefly. }\end{array}$ \\
\hline $\begin{array}{l}\text { “... nonchemical methods for } \\
\text { pest control ... have weaknesses” } \\
\text { (14); the committee calls for } \\
\text { more research on: "selectively } \\
\text { toxic chemicals; (b) nonpersistent } \\
\text { chemicals; (c) selective methods } \\
\text { of application; and (d) } \\
\text { nonchemical control methods" } \\
\text { (21) }\end{array}$ & $\begin{array}{l}\text { "There appears to be no alternative to } \\
\text { chemical pesticides which will not } \\
\text { have some drawbacks of its own or } \\
\text { replace one problem with another." } \\
\text { (26); the recommendations include } \\
\text { encouraging "the chemical industry to } \\
\text { develop chemical pesticides which are } \\
\text { safer for human beings; accelerate the } \\
\text { development of non-chemical pest- } \\
\text { control methods." (68) }\end{array}$ & $\begin{array}{l}\text { "Chemicals, including pesticides ... } \\
\text { are of such importance in modern life } \\
\text { that we must learn to live with them.” } \\
\text { (3); "Recommendation 11: Provide } \\
\text { incentives to industry to encourage the } \\
\text { development of more specific pest } \\
\text { control chemicals.” (17); “... non- } \\
\text { insecticidal control techniques are not } \\
\text { likely to have a significant impact on } \\
\text { the use of insecticides in the } \\
\text { foreseeable future. (21) }\end{array}$ & $\begin{array}{l}\text { Evidence that problematization of } \\
\text { necessity is subverted during the } \\
\text { process of translation: all three } \\
\text { reports are skeptical of the viability } \\
\text { of biological controls and advocate } \\
\text { more targeted, less persistent } \\
\text { chemical substitutes }\end{array}$ \\
\hline $\begin{array}{l}\text { One recommendation is: } \\
\text { "Elimination of the use of } \\
\text { persistent toxic pesticides should } \\
\text { be the goal." (20) }\end{array}$ & $\begin{array}{l}\text { ‘...while most agreed that we should } \\
\text { endeavor to shift away from the use of } \\
\text { persistent toxic pesticides where } \\
\text { possible, few believed that their } \\
\text { complete elimination was a practical } \\
\text { or reasonable goal.” (30) }\end{array}$ & $\begin{array}{l}\text { One recommendation is: "Eliminate } \\
\text { within two years all uses of DDT and } \\
\text { DDD in the United States excepting } \\
\text { those uses essential to the preservation } \\
\text { of human health or welfare...." (8) }\end{array}$ & $\begin{array}{l}\text { All three reports draw normative } \\
\text { conclusions that existing practices } \\
\text { are inappropriate and undesirable; } \\
\text { and they recommend elimination } \\
\text { (although Ribicoff is skeptical of } \\
\text { practicality of full abandonment). }\end{array}$ \\
\hline
\end{tabular}




\section{Table 4: Problematizations in the 1972 Regulatory Decision to Ban DDT}

\begin{tabular}{|c|c|}
\hline $\begin{array}{c}\text { Selected extracts from “Consolidated DDT Hearings: Opinion and Order of } \\
\text { the Administrator of the EPA, William D. Ruckelshaus, June 14, 1972” } \\
\text { (printed in the Federal Register, 37(131), July 7, 1972). }\end{array}$ & Significance \\
\hline $\begin{array}{l}\text { "Public concern over the widespread use of pesticides was stirred by Rachel } \\
\text { Carson's book, “Silent Spring”, and a natural outgrowth was the investigation of } \\
\text { this popular and widely sprayed chemical.”(13369) } \\
\text { “Administrator’s order regarding DDT: In accordance with the foregoing } \\
\text { opinion, findings and conclusions of law, use of DDT on cotton ... is cancelled } \\
\text { as of December 31, 1972.” (13375) }\end{array}$ & $\begin{array}{l}\text { Evidence of impact of problematizations } \\
\text { promoted in Silent Spring. }\end{array}$ \\
\hline $\begin{array}{l}\text { Basic findings re chemical properties, activity in food chain and impact on } \\
\text { organisms, and toxicological effects: "DDT can persist in soils for years and } \\
\text { even decades”; "DDT can persist in aquatic ecosystems”; DDT is a contaminant } \\
\text { of freshwaters, estuaries and the open ocean”; "DDT is concentrated in } \\
\text { organisms and transferred through food webs"; "DDT is toxic to fish”; "Birds } \\
\text { can mobilize lethal amounts of DDT residues"; "DDT can cause thinning of bird } \\
\text { eggshells and thus impair reproductive success.” (13375) }\end{array}$ & $\begin{array}{l}\text { Evidence that problematization of } \\
\text { environmental safety survives translation: } \\
\text { negative impacts are asserted. }\end{array}$ \\
\hline $\begin{array}{l}\text { Basic finding re toxicological effects: "DDT is a potential human carcinogen." } \\
\text { (13375) }\end{array}$ & $\begin{array}{l}\text { Evidence that problematization of human } \\
\text { safety survives translation in qualified form: } \\
\text { DDT is a "potential” carcinogen. }\end{array}$ \\
\hline No mention of resistance. Efficacy of DDT for certain crops is asserted. & $\begin{array}{l}\text { No evidence that problematization of efficacy } \\
\text { survives translation. }\end{array}$ \\
\hline $\begin{array}{l}\text { Basic findings re benefits and matters relating to methyl parathion: "methyl } \\
\text { parathion and other organophosphate chemicals are effective for the control of } \\
\text { cotton pests"; "methyl parathion is a substitute for most crop uses of DDT." } \\
\text { Ultimate finding re benefits: "The use of DDT is not necessary for the } \\
\text { production of crops listed in finding (I)7 [cancelled uses at issue in the hearing, } \\
\text { including cotton and fresh market corn] except that it may be necessary to } \\
\text { produce those crops listed in ... [three minor uses, where users were granted } 30 \\
\text { days to supplement the record before cancellation]." (13375) }\end{array}$ & $\begin{array}{l}\text { Evidence that problematization of necessity } \\
\text { survives translation in subverted form: the } \\
\text { promoted substitutes for DDT are not } \\
\text { biological controls advocated in Silent Spring, } \\
\text { but rather methyl parathion and other } \\
\text { organophosphates, which were criticized in } \\
\text { Silent Spring. }\end{array}$ \\
\hline
\end{tabular}




\section{Table 5: Illustrative Quotes from Counter-texts to Problematizations from Silent Spring}

\begin{tabular}{|c|c|}
\hline Selected extracts from texts authored by Dr. Robert White-Stevens & Significance \\
\hline l and thoroughly researched pesticide” (1969a: 345) & $\begin{array}{l}\text { Countering problematization } \\
\text { of efficacy directly, i.e. } \\
\text { asserting effectiveness of DDT }\end{array}$ \\
\hline
\end{tabular}




\section{Figure 1}



Source: EPA, 1975: 149. 


\begin{tabular}{|c|c|c|}
\hline Chapter & Summary & References \\
\hline $\begin{array}{l}\text { 1) A Fable for } \\
\text { Tomorrow }\end{array}$ & $\begin{array}{l}\text { Vision of a world poisoned by } \\
\text { agricultural chemicals. }\end{array}$ & 0 \\
\hline $\begin{array}{l}\text { 2) The Obligation to } \\
\text { Endure }\end{array}$ & $\begin{array}{l}\text { Overview of themes and } \\
\text { arguments. }\end{array}$ & 4 \\
\hline 3) Elixirs of Death & $\begin{array}{l}\text { Introduction of DDT and other } \\
\text { agricultural chemicals. }\end{array}$ & 70 \\
\hline $\begin{array}{l}\text { 4) Surface Waters and } \\
\text { Underground Seas }\end{array}$ & $\begin{array}{l}\text { Impacts on ground and surface } \\
\text { waters, aquatic life. }\end{array}$ & 17 \\
\hline 5) Realms of the Soil & $\begin{array}{l}\text { Impacts on soil and soil } \\
\text { organisms. }\end{array}$ & 17 \\
\hline $\begin{array}{l}\text { 6) Earth’s Green } \\
\text { Mantle }\end{array}$ & $\begin{array}{l}\text { Impacts on plants and } \\
\text { vegetation. }\end{array}$ & 42 \\
\hline 7) Needless Havoc & $\begin{array}{l}\text { Impacts on wildlife, including } \\
\text { some birds. }\end{array}$ & 17 \\
\hline 8) And No Birds Sing & Impacts on birds. & 49 \\
\hline 9) Rivers of Death & Impacts on fish. & 41 \\
\hline $\begin{array}{l}\text { 10) Indiscriminately } \\
\text { from the Skies }\end{array}$ & Aerial spraying campaigns. & 47 \\
\hline $\begin{array}{l}\text { 11) Beyond the Dreams } \\
\text { of the Borgias }\end{array}$ & $\begin{array}{l}\text { Residues and day-to-day } \\
\text { exposure in the home. }\end{array}$ & 14 \\
\hline 12) The Human Price & Impacts on human health. & 26 \\
\hline $\begin{array}{l}\text { 13) Through a Narrow } \\
\text { Window }\end{array}$ & $\begin{array}{l}\text { Cell-level impacts; } \\
\text { reproduction; mutagenicity. }\end{array}$ & 59 \\
\hline 14) One in Every Four & $\begin{array}{l}\text { Cancer; carcinogenic effects } \\
\text { of agricultural chemicals. }\end{array}$ & 57 \\
\hline 15) Nature Fights Back & $\begin{array}{l}\text { Impacts on insect predator- } \\
\text { prey relations. }\end{array}$ & 34 \\
\hline $\begin{array}{l}\text { 16) The Rumblings of } \\
\text { an Avalanche }\end{array}$ & $\begin{array}{l}\text { Impacts on genetics of target } \\
\text { species populations. }\end{array}$ & 32 \\
\hline 17) The Other Road & $\begin{array}{l}\text { Successful biological } \\
\text { alternatives. }\end{array}$ & 60 \\
\hline
\end{tabular}

Figure 2: Structure and Problematizations of Silent Spring

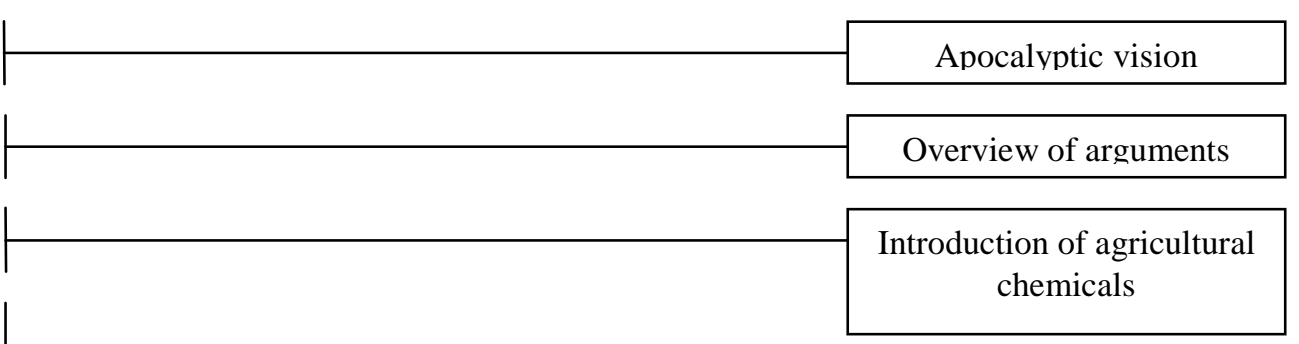

Spraying and ubiquity of

exposure in environment

Negative impacts on

non-human species

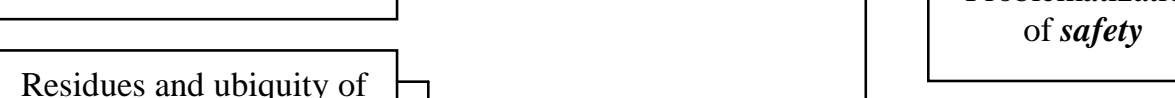

Residues and ubiquity

exposure in home

Safety for humans

Negative impacts on humans

Problems of resurgence and secondary pests

Problems of resistance

Problematization of efficacy

\begin{tabular}{|c|}
\hline Problems of resistance \\
\hline
\end{tabular}

Problematization of necessity 
Figure 3a: Number of PhD Dissertations on DDT, by Topic, by Year

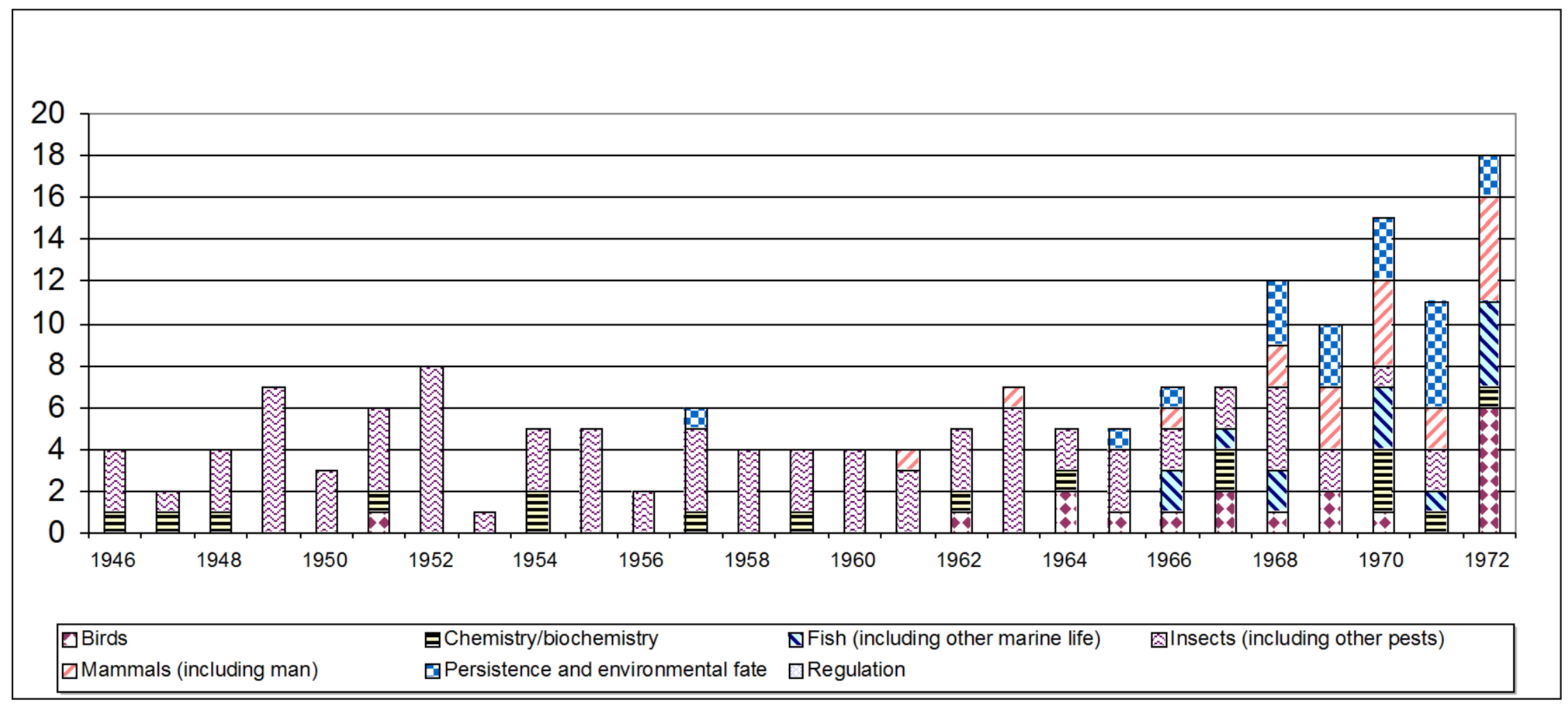




\section{Figure 3b: Number of Articles on DDT in Science, by Topic, by Year}

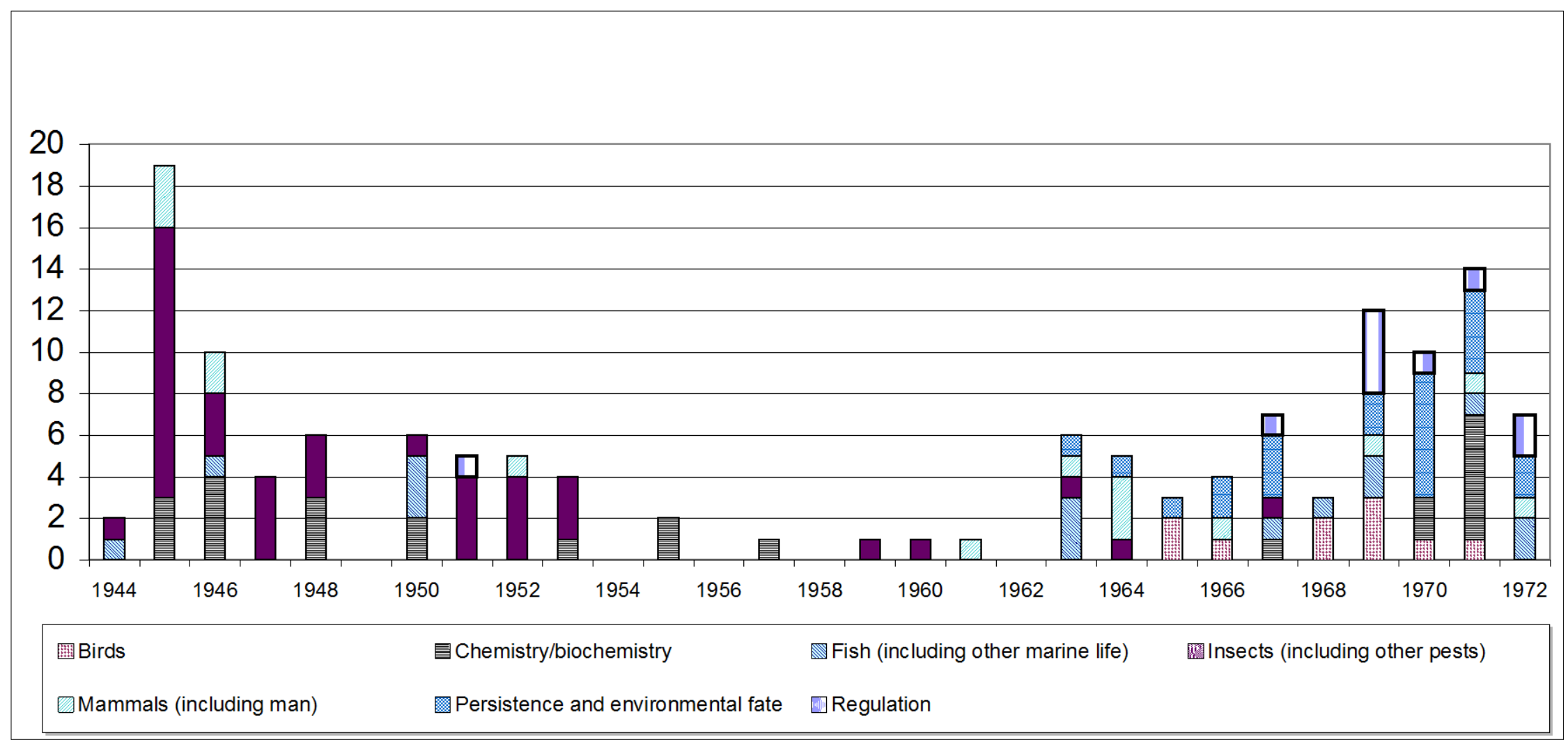




\section{Biographies}

Steve Maguire ( steve.maguire@mcgill.ca ) is Associate Professor of Strategy and Organization in the Desautels Faculty of Management at McGill University. His research focuses on institutional and technological change resulting when commercial, scientific and political struggles intersect around social or environmental issues. For example, his doctoral dissertation draws lessons from society's experience with the insecticide DDT and was awarded the Academy of Management's "Organization and Natural Environment (ONE)” Best Doctoral Dissertation Award in 2001. He has also studied the pharmaceutical industry, analyzing the impact of the empowerment of people living with HIV/AIDS on the commercialization, availability and accessibility of HIV/AIDS treatments.

Cynthia Hardy ( chardy@unimelb.edu.au ) is Professor of Management at the University of Melbourne and co-director of the International Centre for Research on Organizational Discourse, Strategy \& Change. Her recent research includes a focus on institutional entrepreneurship and institutional change from a discursive perspective, and has been published in the Academy of Management Journal and the Academic of Management Review. She has also co-edited a special issue of Organization Studies on institutional entrepreneurship. Other research interests revolve around the study of power and politics in organizations, organizational discourse theory, and critical discourse analysis. She is co-author of Discourse Analysis: Investigating Processes of Social Construction, as well as co-editor of a special issue of Organization Studies on organizational discourse and the Sage Handbook of Organizational Discourse. In total, she has written over 60 journal articles and book chapters; and published twelve books and edited volumes. 


\section{University Library}

\section{- M M I E E R VA A gateway to Melbourne's research publications}

Minerva Access is the Institutional Repository of The University of Melbourne

Author/s:

Maguire, S; Hardy, C

Title:

DISCOURSE AND DEINSTITUTIONALIZATION: THE DECLINE OF DDT

Date:

2009-02-01

Citation:

Maguire, S. \& Hardy, C. (2009). DISCOURSE AND DEINSTITUTIONALIZATION: THE DECLINE OF DDT. ACADEMY OF MANAGEMENT JOURNAL, 52 (1), pp.148-178. https:// doi.org/10.5465/AMJ.2009.36461993.

Persistent Link:

http://hdl.handle.net/11343/116431 